Annu Rev Pathol. 2011 ; 6: 19-48. doi:10.1146/annurev-pathol-011110-130327.

\title{
The Pathogenesis of Sepsis
}

\author{
Deborah J. Stearns-Kurosawa ${ }^{1}$, Marcin F. Osuchowski ${ }^{2}$, Catherine Valentine ${ }^{3}$, Shinichiro \\ Kurosawa $^{1}$, and Daniel G. Remick ${ }^{1}$ \\ Deborah J. Stearns-Kurosawa: dstearns@bu.edu; Daniel G. Remick: remickd@bu.edu \\ ${ }^{1}$ Department of Pathology and Laboratory Medicine, Boston University School of Medicine, \\ Boston, Massachusetts 02218 \\ 2Ludwig Boltzmann Institute for Experimental and Clinical Traumatology, Trauma Research \\ Center, AUVA, A-1200 Vienna, Austria \\ ${ }^{3}$ Department of Internal Medicine, Boston University School of Medicine, Boston, Massachusetts \\ 02218
}

\begin{abstract}
Sepsis is a serious clinical condition that represents a patient's response to a severe infection and has a very high mortality rate. Normal immune and physiologic responses eradicate pathogens, and the pathophysiology of sepsis is due to the inappropriate regulation of these normal reactions. In an ideal scenario, the first pathogen contact with the inflammatory system should eliminate the microbe and quickly return the host to homeostasis. The septic response may accelerate due to continued activation of neutrophils and macrophages/monocytes. Upregulation of lymphocyte costimulatory molecules and rapid lymphocyte apoptosis, delayed apoptosis of neutrophils, and enhanced necrosis of cells/tissues also contribute to the pathogenesis of sepsis. The coagulation system is closely tied to the inflammatory response, with cross talk between the two systems driving the dysregulated response. Biomarkers may be used to help diagnose patients with sepsis, and they may also help to identify patients who would benefit from immunomodulatory therapies.
\end{abstract}

\section{Keywords}

neutrophils; lymphocytes; costimulatory molecules; coagulation; biomarkers; therapy

\section{CLINICAL VIGNETTE}

A 56-year-old woman with obesity, type II diabetes, and diverticulosis develops sepsis. On March 1, while she is lifting a large box, a colonic diverticulum ruptures, spilling intestinal bacteria into the peritoneum. On March 3, she presents to her physician, complaining of abdominal pain, and is admitted to the hospital. Leukocytosis, fever, and an increased heart rate are present, and a diagnosis of sepsis is made. On March 5, the patient develops disseminated intravascular coagulopathy, becomes hypotensive, and is transferred to the intensive care unit (ICU).On March 6 she develops respiratory failure, which requires mechanical ventilation, and on March 8 hemodialysis is initiated for worsening renal failure. The patient's severe problems gradually resolve, and she is discharged on March 27,

Copyright (C) 2011 by Annual Reviews. All rights reserved DISCLOSURE STATEMENT

The authors are not aware of any affiliations, memberships, funding, or financial holdings that might be perceived as affecting the objectivity of this review. 
although by May 1 (60 days since she developed sepsis), she still has not returned to work. This article reviews the major pathologic alterations that compromised this patient's life.

\section{EPIDEMIOLOGY OF SEPSIS}

Sepsis is a severe, debilitating clinical condition that substantially alters the lives of those afflicted. The systemic inflammatory response syndrome (SIRS) is defined by the presence of two or more of the criteria listed in Table 1. When SIRS results from an infection, the clinical diagnosis is sepsis. A positive pathogen culture is not necessary to establish sepsis if there is a strong clinical suspicion of an infection [such as finding neutrophils in a normally sterile environment (e.g., the peritoneum)]. Severe sepsis occurs when the septic process has become so severe that at least one organ has become dysfunctional, and septic shock refers to hypotension due to severe sepsis. In order of severity: Septic shock is worse than severe sepsis, which is worse than sepsis. The patient in our vignette has had septic shock and severe sepsis since she developed hypotension.

A 2009 review (1) of an international registry of patients with severe sepsis demonstrates some basic characteristics of the septic disease process on the basis of data from more than 11,000 patients from 37 countries. Of these patients, $57 \%$ had gram-negative infections, $44 \%$ had gram-positive infections, and $11 \%$ had fungal infections (some had mixed infections, so the total is $>100 \%$ ). The lung was the primary source of the infection in $47 \%$ of the patients, followed by the abdomen (23\%) and urinary tract (8\%). A substantial proportion of the patients had comorbidities, including diabetes (24\%), chronic lung disease or cancer $(16 \%)$, congestive heart failure (14\%), and renal insufficiency $(11 \%)$-again, similar to the patient in our vignette. The mortality from this database was nearly $50 \%$, which indicates that sepsis remains a highly lethal syndrome. During the time of patient enrollment into the database, there was no decrease in sepsis mortality. Understanding the pathogenesis of sepsis will be an important first step in improving survival.

\section{INTERACTION WITH PHAGOCYTIC CELLS}

A bacterial pathogen typically enters a sterile site in which the resident cells detect the invader and initiate the inflammatory response. When a limited number of bacteria invade, the local responses are sufficient to clear the pathogens. Macrophages phagocytose bacteria and produce a range of proinflammatory cytokines, which initiate the innate immune system's response to the bacterial pathogen (2). This process almost certainly occurred during the first few days of infection in our patient, after the rupture of her colonic diverticulum. These macrophages are considered to be polarized toward an M1 phenotype when they begin to produce interleukin (IL)- $1 \beta$, tumor necrosis factor (TNF), and IL-6, as well as chemokines such as IL-8 (CXCL8). (Additional information concerning biomarkers is presented below.) Both resident and recruited antigen presenting cells (APCs) such as macrophages and dendritic cells can alert the host to the presence of infection through the recognition of pathogenassociated molecular patterns, which are conserved microbial molecules that are present in a broad array of bacteria, fungi, and viruses. Such molecules are recognized by pathogenrecognition receptors (PRRs) on APCs, which respond by secreting cytokines that contribute to the innate inflammatory response. The bestdescribed examples of PRRs are Toll-like receptors, which recognize a range of bacterial cell-wall lipoproteins and lipopolysaccharide, as well as fungal-wall elements and bacterial and viral nucleic acids. As part of the innate response, the costimulatory molecules CD80 and CD86 are upregulated following macrophage interactions with bacteria, and they participate in innate-adaptive immune interactions (described below).

In an optimal response to the invasion of bacteria into a sterile space, such as in our patient, the resident peritoneal macrophages contain the initial release of bacteria from the ruptured 
diverticulum. Local control is ideal, and the patient experiences few deleterious consequences, although peritoneal adhesions may develop. If the bacteria overwhelm this first line of defense, then hopefully the newly recruited neutrophils are sufficient to eradicate the bacteria.

\section{INFLAMMATORY CELLS; RECRUITMENT AND ERADICATION OF PATHOGENS}

Additional cells are typically recruited to the site of inflammation to assist with the eradication of the pathogen. The cytokines secreted by the resident inflammatory cells stimulate the synthesis of adhesion molecules on the surface of endothelial cells (3). Circulating white blood cells transiently bind to the endothelial cells, and then are recruited through the vascular wall to the site of inflammation. MicroRNAs have also been implicated in the regulation of adhesion molecules.

The peripheral blood contains several different cell types, including neutrophils, lymphocytes, and monocytes. In normal humans, neutrophils are the most common cells, constituting more than $50 \%$ of the cells in the blood. Neutrophils are also known as polymorphonuclear leukocytes because their nuclei may have numerous shapes. Neutrophils and macrophages are known as phagocytic cells.

Both neutrophils and macrophages kill bacteria by a number of processes. Some of these processes are necessary, and others are redundant, but virtually all require energy (Figure 1). The first step in phagocytic-cell killing of bacteria involves phagocytosis of the pathogen. When bacteria enter the host, they are typically opsonized, that is, covered with host proteins including antibodies and fragments of complement. There are several different receptors (the PRRs described above) on the surface of the neutrophil that assist phagocytosis by recognizing the opsonized proteins on the surface of the bacteria. Two examples of these PRRs are receptors for complement and receptors for the $\mathrm{Fc}$ portion of immunoglobulins.

Combinations of processes within the neutrophils are responsible for killing the bacteria. The phagocytosed bacteria is typically inside a vacuole, the phagosome, which fuses with specific intracellular granules to form the phagolysosome (4). Neutrophils naturally contain granules that have antimicrobial properties. The primary (azurophilic) granules contain adefensins, antibiotic proteases including cathepsin $\mathrm{G}$ and elastase, and myeloperoxidase and bacterial permeability-increasing protein. Secondary granules also contain antimicrobial peptides such as lysozyme, lactoferrin, and met alloproteases. Fusion of the neutrophil granules with the bacteria creates a hostile local environment, with decreased $\mathrm{pH}$ and potent proteases that focus on killing the pathogen. However, there are other mechanisms, including oxygendependent killing, wherein neutrophils generate a respiratory burst by producing reactive oxygen intermediates such as superoxide anion and hydroxyl radicals.

Under ideal circumstances, this potent combination of mediators is contained within the phagolysosome, the bacteria quickly die, and the host survives. But the circumstances are not always ideal, and sepsis may occur when the bacteria escape, or the host response may injure the host. Upon contact with bacteria, neutrophils generate extracellular antimicrobial responses known as neutrophil extracellular traps (NETs), which are composed of portions of the neutrophil's DNA combined with antimicrobial peptides from the granules, as well as histones. NETs have antimicrobial activity.

Sepsis develops when the inflammatory response to infection rises to such a level that physiologic alterations within the host occur. This response is sometimes termed an exuberant or exaggerated inflammatory response, but this may not be an appropriate 
characterization. The bacterial load may be of suchmagnitude (or the bacteria may be so virulent) that a strong inflammatory response appropriately matches the powerful bacterial stimulus, yet the "collateral damage" it simultaneously produces cannot be compensated for by the septic patient. In this context, an anti-inflammatory intervention is a double-edged sword: For example, it may reduce the toxic effects of the inflammatory response but may also compromise effective host protection from the infection. It is widely recognized that immunocompromised patients are at increased risk for sepsis and other infections.

\section{LYMPHOCYTES}

During bacterial infections, there are extensive interactions between APCs and lymphocytes, which are key effector cells in the adaptive immune response. Microbial antigen is presented to $\mathrm{T}$ cells by APCs, in conjunction with other cell-surface proteins such as CD3 and costimulatory molecules. When the appropriate signals are received, effector $\mathrm{CD}^{+}{ }^{+} \mathrm{T}$ cells secrete cytokines, such as interferon (IFN)- $\gamma$, that activate phagocytotic cells to kill intracellular bacteria and interact with B cells, which then produce antimicrobial antibodies. In addition, T cells upregulate expression of CD40 ligand, which binds to CD40 on APCs. This process induces the release of IL-12 and sustains the expression of costimulatory molecules, thereby further promoting innate-adaptive communication.

Septic patients experience a significant decline in the number of lymphocytes through apoptosis, which is considered an important contributing factor to the immunosuppressive state, frequently observed in the later stages of sepsis, that makes patients vulnerable to new infections $(5,6)$. Immunohistochemical staining of spleens obtained postmortem from septic patients show decreased numbers of splenic B cells and $\mathrm{CD}^{+} \mathrm{T}$ cells. Similarly, a lower percentage of $\mathrm{CD}^{+} \mathrm{T}$ lymphocytes is found in the peripheral blood of patients with sepsis relative to healthy controls. Notably, as a patient's sepsis resolves, the degree of T cell apoptosis correspondingly decreases (7-9).

Splenic T cells from mice that have undergone a so-called two-hit model consisting of (a) cecal ligation and puncture (CLP), leading to a mixed microbial infection, followed 5 days later by $(b)$ intravenous challenge with Pseudomonas aeruginosa produce lower levels of IFN- $\gamma$. However when such splenic T cells are stimulated ex vivo with IL-12, they respond with similar levels of IFN- $\gamma$ as controls. This finding suggests that after the initial infectious insult, $\mathrm{T}$ cells may not receive the appropriate stimulus from APCs in order to respond adequately to a second infection (10). A potential mechanism for this loss of $\mathrm{T}$ cell function during sepsis is that signals received from APCs via costimulatory molecules are altered and induce anergy and apoptosis. Findings supporting this theory are that cytotoxic $\mathrm{T}$ lymphocyte-associated antigen (CTLA)-4/CD152 (an inhibitory costimulatory ligand on T cells) expression is increased on $\mathrm{T}$ lymphocytes in patients with sepsis and is accompanied by the downregulation of CD86 [a costimulatory molecule (CSM)] expression on monocytes. Longitudinal measurements performed on patients with sepsis show a reduction in $\mathrm{T}$ cell apoptosis in survivors that is associated with a decrease in CTLA-4 expression and upregulation of $\mathrm{CD} 86$ (11).An increase in $\mathrm{CD} 4^{+} \mathrm{CD} 25^{+}$regulatory T cells (Tregs) is observed in septic patients and is another possible cause of diminished lymphocyte activity. Ex vivo studies demonstrate decreased $\mathrm{T}$ cell proliferative response to antigen in wholeblood samples from septic patients, whereas silencing of Foxp3 (a transcription factor necessary for Treg function) expression in splenocytes from septic mice restores the proliferative response $(12,13)$.

\section{COSTIMULATORY MOLECULES}

The surge of proinflammatory cytokines during the innate immune response is a clinically visible and widely studied aspect of the pathophysiology of sepsis (see the section entitled 
Biomarkers, below). Increasing data indicate that interactions between APCs and the adaptive immune system play a key role in the host response during sepsis. These interactions certainly developed in our septic patient when the resident macrophages and recruited neutrophils failed to contain the initial infection. We are learning more about the interplay between the two arms of the immune system, how the innate response plays a significant role in determining the nature of the adaptive response, and how this response may affect long-term outcomes in septic patients. Monocytes isolated from septic mice demonstrate a decreased capacity for $\mathrm{T}$ cell stimulation, and marked apoptosis of lymphocytes in septic patients is frequently observed $(11,14,15)$. CSMs are cell-surface proteins and are an important component of the immunological synapse between the APC and the T cell (Figure 2). They are expressed on APCs, which participate in the regulation of $\mathrm{T}$ cell activation by providing crucial second signals; such signals lead to $\mathrm{T}$ cell activation and proliferation, or inhibition, which in turn causes anergy and apoptosis (16).

The best-characterized CSMs, which belong to the B7 family, are CD80 (B7-1) and CD86 (B7-2). These CSMs serve as ligands to the CD28/CTLA-4 receptors on T cells, are expressed on APCs, and are upregulated in response to multiple microbial stimuli. As with many signaling systems, there is additional complexity: CD80 and CD86 can bind to either CD28 or CTLA-4 and can deliver stimulatory or inhibitory signals, respectively. CD28 is constitutively expressed on T cells, and ligation results in $\mathrm{T}$ cell activation and proliferation, whereas CTLA-4 is upregulated only after T cell activation and serves to limit the T cell response to antigen $(16,17)$. The potential significance of the $\mathrm{B} 7: \mathrm{CD} 28$ pathway in the innate response was emphasized by a clinical trial (18) of a CD28 monoclonal agonist antibody. In this trial, humans infused with the antibody developed a severe inflammatory response and clinical symptoms typical of sepsis.

In mice that have undergone CLP, which mimics bowel perforation and development of sepsis in a human patient (such as ours), expression of CD80 is increased on peritoneal, splenic, and peripheral-blood mono-cytes. Conversely, CD86 is downregulated in the peritoneum, whereas its expression is increased in the spleen and peripheral blood $(14,19)$.

This variability in expression suggests that although there is considerable overlap in both sequence and ligands, CD80 and CD86 expression may serve different functions, depending on the location of the APCs relative to the site of infection. Such compartmentalization has also been observed in the cytokine response to infection (20), and it may be key to the ability of a severe localized infection to eventually cause a systemically immunosuppressed state, as is frequently observed in later stages of sepsis (21-23).

There are also differences between the levels of CD80 and CD86 expression with respect to survival in sepsis. $\mathrm{CD} 80^{-/-}$mice, or mice that receive anti-CD80 monoclonal antibody prior to CLP, demonstrate a marked increase in survival relative to wild-type controls and $\mathrm{CD}^{-1-}$ animals. In septic patients in the ICU, an increase in CD80 expression on circulating monocytes is observed. Higher levels, associated with shock, suggest a negative effect of CD80, although there is no association with survival. Comparatively, CD86 expression on these cells is decreased relative to healthy control subjects, but interestingly, within the group of septic patients higher levels of expression are found in survivors versus nonsurvivors $(11,19,24)$.

Another CSM that promotes immune response to infection is CD40, along with its T cell ligand CD154 (often referred to as CD40L) (25-27). CD40 expression by macrophages is necessary for effective phagocytosis of bacteria (28), which is a critical first step in the host response to infection. When T cells are activated, CD40L expression on T cells is increased, which upon binding to CD40 on APCs further upregulates expression of CD80 and CD86 
and induces the release of IL-12, which promotes T cell activation and differentiation. CD40 expression is increased in septic mice, and $\mathrm{CD} 40^{-/-}$mice have both decreased mortality from CLP, relative to wild-type controls, and decreased serum levels of IL-6. CD40 expression is increased on peripheral-blood mononuclear cells in humans with sepsis; higher levels are associated with shock (29). However, higher levels of expression also correlate with survival, and mice that receive an agonistic anti-CD40 antibody have decreased lymphocyte apoptosis and improved survival after CLP (30).

Other B7 family members of interest are PD-L1 and PD-L2, which deliver inhibitory signals via the T cell receptor PD-1, resulting in anergy and apoptosis. PD-L1 is constitutively expressed on splenic T cells, B cells, and APCs, as well as on a broad range of nonhematopoietic cells. PD-L2 is more restricted and is inducible only on dendritic cells, macrophages, bone marrow-derived mast cells, and specific peritoneal B cells $(31,32)$. Expression of PD-1 is increased on T cells in HIV and other chronic viral infections. PD- $1^{-/}$mice are more resistant to infection with Listeria monocytogenes, which suggests that this signaling pathway may play a significant role in the ability of the host to clear pathogens (33-35). Although PD-L1 and PD-L2 have not yet been specifically examined in sepsis patients, PD-1 has been studied in bacterial infection and sepsis in mice. PD- $1^{-/-}$ mice subjected to CLP show a lower mortality and decreased inflammatory cytokine production and bacterial load both systemically and locally in the peritoneum (36). These findings are somewhat surprising, considering that one might expect the absence of a T cellinhibitory pathway to cause a greater inflammatory response because activated $\mathrm{T}$ cells release IL-2, which promotes the activation of cytotoxic T cells. Although the current data are still somewhat limited, it is evident that CSMs are an integral part of the host response to infection and that they play a key role in the dysregulation of the complex equilibrium between an inappropriate inflammatory response and the clearance of infection observed during sepsis.

\section{APOPTOSIS AND NECROSIS}

Nearly $40 \%$ of sepsis cases end in death within 28 days. Death of individual cells has great significance in the pathophysiology of sepsis. There are two major types of individual cell death: apoptosis and necrosis. In this section, we discuss the apoptotic and necrotic pathways and how they affect discrete cell types. Our patient almost certainly had dysregulated apoptosis and necrosis of inflammatory cells as she progressed through her septic state.

\section{Apoptosis}

Apoptosis is termed programmed cell death because it is a series, or program, of coordinated processes (37). During apoptosis, the integrity of the plasma membrane remains intact until near the end of the process. With intact plasma membranes, toxic substances from inside the cell are typically not released into the surrounding environment. Morphologically apoptotic cells undergo DNA fragmentation, chromatin condensation, nuclear fragmentation, and the formation of blebs from the plasma membrane. Apoptotic cells may be detected by various techniques, including demonstration of chromatin laddering, caspase activation, and staining for terminal deoxynucleotidal transferase. Apoptosis is an important aspect of normal development and the regulation of cellular proliferation. During organ development, apoptotic pathways remove those cells that are no longer necessary: It is estimated that without removal of cells through apoptosis, 2 tons of bone marrow and lymph nodes would accumulate during a person's lifetime (38). Additionally, apoptosis may be responsible for the removal of malignant cells, and some neoplasms represent a failure of apoptosis. 
Apoptosis is induced through two major signaling cascades, which are termed the extrinsic and intrinsic pathways (39). In the extrinsic pathway, external proteins bind to cell-surface receptors that subsequently induce apoptosis. This pathway has also been termed the death receptor pathway (40). Several different molecules are involved, including TNF, TRAIL, and FAS. Upon binding to the receptor, the adaptor protein FAS-associated death domain is recruited to the inner surface of the cell membrane. This event initiates a cascade of intracellular events, which include the upregulation of inhibitors-of-apoptosis proteins to provide negative feedback. Eventually caspase- 3 becomes activated; caspase- 3 has been termed the master executioner (41).

The intrinsic pathway is the mitochondrial mediated pathway of apoptosis. In this pathway, oxygen radicals, $\gamma$ radiation, or DNA injury plays a central role. A balance exists between (a) antiapoptotic proteins such as BCL-2, BCL-XL, and several others; and (b) proapoptotic proteins such as Bim, Bax, and PUMA. There is a link between discrete proteins and the initiating apoptotic signal; for example, PUMA regulates apoptosis induced by DNA damage. The proapoptotic proteins induce mitochondria to release cytochrome $c$, which through a series of events activates caspase-9. As in the extrinsic pathway, caspase-3 becomes activated as a terminal event.

\section{Necrosis}

Necrosis is the other major pathway by which cells die. Classically, necrosis occurs during is-chemic injury, when there is rapid depletion of intracellular stores of ATP. The necrotic cell compromises cellular membranes that allow leakage of injurious, proteolytic enzymes. These enzymes leak into the cytoplasm from intracellular organelles, such as lysosomes, or into the surrounding tissue if the plasma membrane loses integrity. These are the same proteins that are used to destroy bacteria during the initial response to infection as described in the section on phagocytic cells. The importance of apoptosis versus necrosis in sepsis has been highlighted by adoptive transfer experiments. In septic mice, injection of apoptotic cells increased mortality, whereas injection of necrotic cells decreased mortality (42).

\section{Apoptosis of Specific Cells and Its Role in Sepsis}

Although necrosis has been observed both in septic patients and in animal models of sepsis and endotoxemia, evidence suggests that cell loss related to apoptosis is of much greater clinical relevance in this disease (6). Although the incidence of apoptosis has been reported in cell types including endothelial, neuron, and muscle cells, the most pronounced apoptosis during sepsis occurs in two discrete cell populations: lymphocytes and gastrointestinal epithelial cells (43). The Hotchkiss group (8) first reported this seminal evidence in humans by performing technically challenging, rapid autopsies of patients who died from sepsis. The authors showed that accelerated apoptosis is frequently found in lymphoid organs such as the spleen and thymus, as well as in the lymphoid portions of other organs such as the large intestine. In contrast, it is relatively rare in nonlymphoid tissues. Moreover, the infrequent incidence of apoptosis observed in organs such as the liver, or in epithelial cells in the kidneys and lungs, was not associated with the organ injury present in these patients (8). Subsequent studies in spleens of septic patients by the same group $(9,44)$ revealed that B cell and $\mathrm{CD} 4^{+} \mathrm{T}$ subsets of lymphocytes and dendritic cells (both follicular and interdigitating) were especially vulnerable to apoptosis, whereas other $\mathrm{T}$ cell subsets and macrophages remained largely intact. A similar apoptotic pattern was later reported in pediatric and neonatal patients who died of sepsis (15). Accelerated lymphocyte apoptosis is equally widespread in circulating subpopulations of lymphocytes and causes persistent lymphopenia in septic patients (5). As in splenic lymphocytes, apoptosis predominates in circulating $\mathrm{CD}^{+} \mathrm{T}$ cell and $\mathrm{B}$ cell subsets, but depletion of $\mathrm{CD}^{+} \mathrm{T}$ cells and natural killer cells has also been observed (7). Interestingly, in both studies $(5,7)$ the degree of apoptosis 
closely correlated with the severity of sepsis symptoms and outcome in patients with sepsis and septic shock.

The above findings largely agree with observations made in animal studies. The intensity of lymphocyte apoptosis in lymphoid tissues and gut epithelium in the murine CLP model of polymicrobial sepsis is similar to the depletion reported in septic patients (45). Additional nonlymphoid sites and cell subsets that appear somewhat vulnerable to apoptosis after CLP sepsis include lung endothelial cells (alveolar, respiratory, and capillary), kidney tubular cells, and skeletal muscle cells (46). Interestingly, despite CLP-induced lymphopenia in the acute phase of sepsis, a number of studies reported higher counts of peripheral lymphocytes (although without defining the proportions of nonapoptotic versus apoptotic cells) in dying animals than in surviving animals $(47,48)$.

In the case of neutrophils, delayed apoptosis can be as detrimental as accelerated apoptosis in lymphocytes. Neutrophils, which have robust antibacterial properties and are the first cells to be recruited to the site of infection, play a central role in the containment of the infectious insult. They are also constitutively apoptotic, which ensures tight control of the neutrophil-mediated inflammation. Given that profound inhibition of neutrophil apoptosis has been documented in patients with sepsis (49-51), the delayed apoptosis of neutrophils may contribute to organ injury and mortality in the septic patient. When persistently activated, neutrophils can potentially cause extensive damage to other nearby cells and tissues by continuous release of their soluble toxic products.

Many questions pertinent to apoptosis in septic patients have yet to be answered. The cells or tissues that become apoptotic are probably much more heterogeneous than the existing evidence suggests. On the basis of the source or site of septic insult, new patterns of apoptotic depletion may be discovered. For example, Staphylococcus pyogenes triggers rapid apoptosis of neutrophils and macrophages, whereas Listeria monocytogenes does the same to hepatocytes (37). The recent mouse model that was "humanized" with hCD34+ hematopoietic cord blood stem cells (and that displays a fully functional human innate and adaptive immune system) will be a good launching platform for such studies (52).

Accelerated apoptosis, especially as it occurs in lymphocytes, may play a central role in the pathogenesis of sepsis. This hypothesis was examined in an elegant adoptive transfer experiment in septic mice, as mentioned above (42). Additionally, severe immune depression (also termed immunoparalysis) ensues in the subsequent stages of sepsis (23). Apoptosis-induced loss of lymphocytes may be one of the key triggers of this state. Such immunosuppression is thought to be mediated by two major pathways: direct apoptosis of key effector cells or indirect but apoptosis-induced anergy in surviving macrophages and dendritic cells (43). Because the resulting long-term impairment of immunologic defenses and the subsequent predisposition to secondary infections clearly place the host at a disadvantage, various antiapoptotic interventions have been proposed to either prevent or reverse these processes. Treatments tested to date include overexpression of BCL-2, inhibition of caspases (e.g., caspase-3 and caspase-8) and CD95, and most recently the use of noncaspase protease inhibitors (43). Unfortunately, these experimental treatments have not yet been tested in clinical trials, probably because the complexity of the signaling pathways regulating apoptosis makes them challenging as possible therapeutic targets.

\section{COAGULATION AND SEPSIS}

There is widespread agreement that dysfunctions in coagulation develop during the course of sepsis and lead to inappropriate intravascular fibrin deposition. Any consensus beyond that statement, however, remains frustratingly elusive. There is considerable discussion regarding whether coagulopathy has a pathogenic role in sepsis or is merely a bystander. 
This ongoing debate is fueled by the success (53), failure (54-56), or uncertain ability (57) of anticoagulant compounds to alter 28-day all-cause mortality in sepsis clinical trials. In our patient with severe sepsis and hypotension, disseminated intravascular coagulation (DIC) developed a little over a week after the bacterial infection began. When the natural balance of coagulation (fast onset and fast multilayered inhibition) is unbalanced during disease, small clots form faster than they can be broken down, and they lodge in the microvascular beds of organs. Platelets and coagulation factors are consumed faster than they can be replaced, so patient platelet counts drop, fibrinogen levels decline, and clotting times are prolonged. The paradox of DIC is that the patients are undergoing nearly unrestricted clotting and, as a result, are at high risk for bleeding. Skin petechiae are the visible evidence of the systemic microbleeding associated with the consumption coagulopathy of DIC.

In theory, it should be simple to address this problem. The clots are a physical obstruction in the microvasculature and cause ischemia and reperfusion injury, thereby contributing to multiple organ failure and death. If clot formation is prevented or shut off, then organ function should be preserved. But, in practice, there are multilayered confounders in such settings, including population heterogeneity, comorbidities, and contraindications to standard care therapeutics, such as heparin. In two anticoagulant clinical trials with sepsis patients, heparin administered to these patients may have reduced the activity of the experimental drug $(54,58)$.

\section{Coagulation Checkpoints for Anticoagulation}

Despite these problems, efforts persist to regulate inappropriate clot formation in patients with sepsis. Pharmaceutical intervention typically targets so-called checkpoints during the coagulation cascade, either chemically or with natural regulators of the same molecules. By checkpoint, we mean a molecule that is necessary for successful fibrin formation; such molecules include, at least, tissue factor, the Factor Va and VIIIa cofactors, and Factor Xa (Figure 3). Tissue factor starts the process (in the extrinsic pathway); Factors Va and VIIIa accelerate it; and Factor Xa is the clotting enzyme central to both the extrinsic and intrinsic pathways.

Although anticoagulants have had variable success in sepsis clinical trials, defined coagulation test profiles clearly distinguish between coagulopathy in patients with infection versus coagulopathy in patients with trauma, and can predict outcome (59). In the clinic, two clotting tests are routinely performed. The prothrombin time (PT) is a measure of tissue factor-pathway molecules. Exogenous tissue factor (thromboplastin) is added to patient plasma, and the clotting time is expressed as a ratio (the international normalized ratio) with a standardized reagent value to take into account differences between laboratory reagents. PTs are routinely used to monitor patients on oral anticoagulants, such as warfarin. The activated partial thromboplastin time (APTT) is a measure of the contact activation pathway that leads to Factor Xa activity. Exogenous phospholipid is added to patient plasma, and the time to clot is recorded. APTTs are routinely used to monitor patients on intravenous anticoagulants, such as heparin or low-molecular-weight heparin. There are many tests available to monitor clot formation (Figure 4), regulation of clot formation (Figure 5), or clot breakdown (Table 2). Many tests are used in research, but few are used clinically, such as $\mathrm{D}$-dimer and fibrin degradation products (FDPs), which are good indicators of fibrinolysis and reflect the extent of coagulopathy (60).

Thrombin is the final serine protease created during the cascade. Its primary function in coagulation is to remove two small peptides (fibrinopeptides A and B) from fibrinogen, thereby creating the fibrin monomers that oligomerize. The actions of thrombin are remarkably diverse, with influence on fibrinolysis, inflammation, tumor metastasis, cell proliferation, and angiogenesis, among others, as has been recently reviewed (61). Although 
there is a rationale for inhibiting thrombin during sepsis, because thrombin plays a major role in inflammation via protease-activated receptors (PARs) (62), the use of thrombin inhibitors during the fulminant coagulopathy of severe sepsis is probably too little, too late. Phase II and III clinical trials evaluated hirudin, a direct thrombin inhibitor from the medicinal leech Hirudo medicinalis, or hirudin analogs in patients with acute thrombotic events, but they observed minimal impact on mortality out-come, no overt advantage over standard heparin or low-molecular-weight heparin, and a high incidence of bleeding (63). Studies of mixed microbial sepsis (64) in animal models show inhibition of fibrin deposition, but not improved organ perfusion, after use of hirudin. An-tithrombin is the natural inhibitor of thrombin, yet a large multinational Phase III clinical trial [the KyberSept trial (57)] to assess antithrombin treatment in patients with severe sepsis did not result in improved survival. Notably, however, a meta-analysis of the KyberSept data showed that patient subpopulations with a high (30-60\%) risk of death may benefit greatly from antithrombin treatment (65). This finding provides some optimism for future trials that take patient-stratification criteria into account (also see the Biomarkers section, below).

\section{Targeting Tissue Factor}

Tissue factor (also known as Factor III, thromboplastin, and CD142) is a pluripotent transmembrane cofactor and receptor and is the physiologic initiator of clotting in vivo (66). Tissue factor is expressed either actively in the extravascular space (but normally unavailable to blood components) or in a cryptic form that becomes procoagulant after some poorly defined process. An intriguing model of redox-driven disulfide bonding between Cys186 and Cys209 in tissue factor was proposed to explain how tissue factor switches between high- and low-activity (cryptic) states (67). However, lack of evidence for free thiols in tissue factor and predictions from crystal structure data argue that there is more to the story of how tissue factor activity becomes unmasked (68). Recent studies (69) also demonstrate a soluble tissue factor with prothrombotic activity, the product of alternative splicing that skips over exon 5 and does not attach the transmembrane domain. In coagulation, tissue factor is responsible for binding and activating Factor VII on cell surfaces, thereby forming the enzyme-cofactor complex that results in amplified production of Factor Xa. This is the checkpoint blocked by tissue factor pathway inhibitor (TFPI), which is a product of endothelial cells and platelets (70).

TFPI inhibits the tissue factor-Factor VIIa complex in the presence of Factor Xa, forming a nonfunctional quaternary structure (71). TFPI loosely associates with endothelial cells via binding to their glycocalyx coating, and it is displaceable by heparin. In animal models of bacterial sepsis and human endotoxemia challenge studies, TFPI was a promising treatment for limiting coagulopathy $(72,73)$. However, a Phase III randomized clinical trial (54) in patients with severe sepsis $(n=1,754)$ found that recombinant TFPI (rTFPI) failed to alter 28-day all-cause mortality. Notably, in the patient subpopulation with low international normalized ratio $(<1.2)$ there was a survival benefit $(22.9 \%$ placebo versus $12.0 \%$ rTFPI; $p$ $=0.05$ ) that persisted even after adjustment for treatment, baseline APACHE (acute physiological and chronic health evaluation) score, and $\log _{10}$ IL-6 variables. The increased central nervous system, gastrointestinal, and respiratory bleeding risk in the rTFPI arm and undesirable interaction with therapeutic heparin will probably limit further development of this anticoagulant for sepsis patients.

\section{Targeting Factors Va and VIIIa}

Coagulation uses two cofactors, Factors Va and VIIIa, to greatly amplify the generation of fibrin. These molecules are another checkpoint, and nature designed the protein $\mathrm{C}$ anticoagulant pathway specifically to inhibit both cofactors. On cells, the endothelial protein $\mathrm{C}$ receptor binds the zymogen protein $\mathrm{C}$ precursor and presents it to a preassembled complex 
of thrombin bound to thrombomodulin (CD141), a transmembrane cofactor. This permits efficient cleavage of the precursor to activated protein $\mathrm{C}(74,75)$, which is the serine proteinase that degrades Factors Va and VIIIa by limited proteolysis (76). Without these cofactors, coagulation slows by orders of magnitude, effectively shutting down thrombin production. The protein $\mathrm{C}$ pathway members also have cytoprotective functions (77), which is surely beneficial during the cellular destruction of sepsis (see the Apoptosis and Necrosis section, above), as was most recently demonstrated by the ability of activated protein $\mathrm{C}$ to degrade cytotoxic histones released by damaged cells (78). In the late 1980s, a nonhuman primate study demonstrated that pretreatment with activated protein $\mathrm{C}$ prevented death due to challenge withanotherwise lethal dose of the gram-negative bacteria Escherichia coli (79). This observation culminated in the PROWESS clinical trial (53), and in 2001, the U.S. Food and Drug Administration (FDA) approved recombinant human activated protein $\mathrm{C}$ (drotrecogin alfa, activated) for adjunctive therapy in patients with severe sepsis.

The initial euphoria about a successful clinical trial that improved mortality by $6.1 \%$ and was associated with better long-term organ function in severely septic patients has been tempered by the significant bleeding risk associated with drotrecogin alfa in almost all studies (58), lack of beneficial effects in children (55), and lack of benefit in patients with severe sepsis but low risk of death (80). Drotrecogin alfa is not yet a standard of care, and guidelines restrict its use to patients with an APACHE score of above 25, multiple organ failure, and high risk of death. Early anticoagulation in the most severely ill patients appears to be protective. The 30-country, voluntary Surviving Sepsis campaign (described in the section on Therapeutic Interventions, below) to institute evidence-based comprehensive clinical management of patients with severe sepsis and shock observed that administration of drotrecogin alfa in the first $24 \mathrm{~h}$ after ICU admission was associated with improved survival in the patients with shock (81).

Many studies, including the PROWESS trial, have shown that low circulating protein C levels correlate with disease severity and poor prognosis. Consistent with several earlier small clinical studies, the results from a limited Phase II trial with severely ill children with meningococcemia and a survival window of $12.3 \mathrm{~h}$ showed that reconstitution with protein $\mathrm{C}$ concentrate (the precursor to activated protein $\mathrm{C}$ ) provided benefit and transiently increased circulating activated protein $\mathrm{C}$ levels, thereby restoring some coagulation balance with no adverse bleeding (82). These findings laid to rest the persistent assertion that severely septic patients are functionally unable to activate the protein $\mathrm{C}$ precursor and thus should receive the active enzyme. Recombinant human protein C concentrate (Ceprotin ${ }^{\circledR}$ ) is currently approved for treatment of infants with severe protein $\mathrm{C}$ deficiency, a rare autosomal recessive disorder. A recent report of four preterm infants (median gestational age, 27-34 weeks; median birth weight, 1,410 g) with severe bacterial sepsis, shock, and high risk of death $(80 \%)$ detailed off-label treatment with protein $\mathrm{C}$ concentrate and antithrombin in addition to standard intensive care treatment (83). Within $48 \mathrm{~h}$ of receiving protein $\mathrm{C}$ concentrate, circulating protein $\mathrm{C}$ values normalized, purpuric skin lesions resolved, and the neonatal multiple organ dysfunction score normalized. All four infants survived without thromboembolic or bleeding events and without microcirculation disturbance. There is a real need for clinical trials that evaluate human protein $\mathrm{C}$ concentrate in septic pediatric patients because this population is at high risk for coagulation abnormalities, does not benefit from drotrecogin alfa, and has not been included in other recent therapeutic trials.

\section{Targeting Factor Xa with New Anticoagulants}

Although the leech and its active component hirudin are arguably the oldest anticoagulants used medically, a few successful anticoagulants have been introduced since heparin was first used in the 1930s. Low-molecular-weight heparin (Factor Xa specific; 1987) and vitamin K 
antagonists (warfarin and coumadin; early 1950s) remain the standard of care for anticoagulation despite their associated complications, such as the need for intravenous administration, drug-induced thrombocytopenia, and difficult dosing. Thus, the recent discovery of novel Factor Xa inhibitors that can be administered orally is excellent news. Factor $\mathrm{Xa}$ is another checkpoint in coagulation because it is shared by both the intrinsic and extrinsic clotting pathways and is active sufficiently upstream in the cascade such that its inhibition is effective. One class of new Factor Xa inhibitors based on a pyrazole scaffold (apixaban) has shown good bioavailability in animal models and prophylactic efficacy in patients undergoing knee replacement (84). Perzborn et al. (85) describe the anti-Factor Xa activity of BAY 59-7934 (rivaroxaban), which is from a class of oxazolidinone derivatives, identified during high-throughput screening, that are competitive inhibitors of Factor Xa directed against the enzyme's active site; they have a relatively short half-life but good oral bioavailability. Rivaroxaban has now been successfully tested in animal models of thrombosis, in healthy adults, and prophylactically in patients undergoing major orthopedic surgery (86). None of these new drugs have been tested for treatment of coagulopathy during the septic response. A review of recent studies that reveal a widespread signaling role for Factor Xa via activation of PARs (e.g., PAR-1 and PAR-2) and independently of its coagulation functions (87) suggests that manipulation of this molecule may have multiple consequences, particularly during tissue remodeling, wound healing, and acute lung injuryall of which are sequelae of severe sepsis.

\section{BIOMARKERS}

Biomarkers are molecules that are correlated with disease states or states of altered physiology. Such molecules may not actually cause the disease state, but they do represent a marker of a biological process. A classic example of a biomarker is the plasma level of troponin, which is used to determine whether a patient has an acute myocardial infarction. Biomarkers may be used to diagnose disease and to direct therapies. Given the complexity of the septic response as detailed above, there is great interest in developing biomarkers to accurately diagnose sepsis and to monitor critically ill patients. However, monitoring septic patients has traditionally been achieved by measuring physiologic parameters.

\section{Monitoring Septic Patients: Physiology}

Septic patients — indeed, most ICU patients — are currently monitored by physiologic measurements, such as heart and respiratory rate and blood pressure, as well as by laboratory parameters, including platelet count and serum sodium. However, these routine parameters are not sufficiently robust to permit an accurate diagnosis of sepsis (88). Additionally, scoring systems such as APACHE, SOFA (sequential organ failure assessment), and even the more specific PIRO (predisposition, infection, response, and organ dysfunction) fail to characterize the underlying immunoinflammatory status of septic patients, who may be hyperinflammatory or hypoinflammatory despite identical physiological scores. As a result, numerous Phase III clinical trials demonstrated that therapeutic anti-inflammatory interventions applied in an indiscriminate manner are either completely ineffective or actually harmful (89). The identification of accurate biomarkers, which would allow better patient selection and more appropriate targeting of previously unsuccessful therapeutic approaches, may yield better outcomes. It is unlikely, however, that accurate predictive and diagnostic markers are to be discovered among the currently used assorted physiological measurements.

\section{Monitoring Septic Patients: Immunology}

One could argue that immunomonitoring provides no added benefit over routine clinical monitoring. The value of a immunoinflammatory biomarker lies in its capacity to offer 
timely information beyond the data generated during routine physiologic evaluation, thereby allowing the prospect of successful intervention before the therapeutic window permanently closes (90). Given that sepsis is characterized by an unusually complex

immunoinflammatory response, it is intuitive to look for clues among various components of this response.

In human sepsis, several inflammation-associated biomarkers, such as inflammatory cytokines (both pro- and anti-inflammatory), procalcitonin (PCT), and C-reactive protein (CRP), were initially claimed to be either of diagnostic value or correlated with death (8992). Historically, PCT has been one of the most promising diagnostic markers used to differentiate sepsis from other noninfectious causes of SIRS. Moreover, PCT has been considered as a potential therapeutic target because its administration to septic animals exacerbated mortality, which was subsequently alleviated after neutralization of calcitonin precursors (91). Despite the ongoing debate regarding PCT use in critical care settings (91), a number of clinical trials are actively investigating the utility of PCT immunomonitoring in septic patients. For example, daily PCT levels are being evaluated to determine whether measurements can be used to either improve outcome (PASS trial; http:// www.clinicaltrials.gov identifier NCT00271752) or guide (SISPCT trial; NCT00832039) and limit the duration of (Pro-SEPS trial; NCT01025180) antimicrobial therapy in septic patients. In contrast to PCT, controversy exists as to whether another promising biomarker, IL-6, significantly contributes to sepsis severity or merely constitutes a marker of the disease (93). Despite this argument, IL-6 remains an important contender as a predictor of subsequent septic complications (e.g., organ dysfunction) and mortality in both human (89, 94) and animal models (95). CRP does not play a major role in diagnosis, and prediction of outcome in sepsis due to its low specificity $(90,96)$.

Despite the intense investigative focus on humoral biomarkers, dramatic immunoinflammatory changes have also been noted in cellular compartments (e.g., leukocytes) of septic patients (6). This prompted investigators to evaluate several cellular constituents as markers for sepsis. HLA-DR and fractalkine receptor (CX3CR1) expression on monocytes correlated with the immune status of the patient; they had lower expression when the patient is in the stage of immunosuppression in clinical sepsis $(97,98)$. The depletion of lymphocytes in septic patients coincides with a poor outcome and prevention of lymphocyte apoptosis in animal models of sepsis dramatically improved survival (6). Higher levels of neutrophil expression of CD64 were highly predictive for detection and prognostication of sepsis in hospitalized patients (99). Similarly, circulating endothelial progenitor cells accurately detect and define the onset and severity of the disease in septic patients (100).

\section{Value of Immunomonitoring}

Biomarker-based immunomonitoring offers a versatile approach for various disease and prevention scenarios (90). In sepsis, the investigative spotlight has been directed toward diagnosis and prognosis. Additionally, efforts have been launched to determine whether biomarkers can allow early termination of antibiotics (as indicated above). The utility of a biomarker for the diagnosis of sepsis should be judged on its ability to shorten the time necessary to make a diagnosis, improve discrimination between infectious and noninfectious causes of inflammation, enhance differentiation of viral from bacterial infections, and assess appropriate control of the infection (90). The first two elements are especially important because early therapy dramatically improves survival in septic patients (101). Regardless of the number of novel interventions in the experimental pipeline, timely antibiotic administration remains a fundamental component of the early therapy in sepsis: Each hour of delay in effective antimicrobial treatment in septic shock patients decreased their survival 
by approximately $8 \%(102)$. Set against the "gold standard" of the blood culture and SIRS criteria, biomarkers are expected to reduce this critical waiting time. Such an end point, although deliverable, has a critical weakness in that it identifies sepsis but not the pathogen. Commercial (e.g., Lumitest, Brahms PCT-Q, and Kryptor PCT assays by Brahms Diagnostica) and experimental biomarker-based tests that aid in the identification of a bacterial infection (and allow the early initiation of antibiotics) in ICU patients fail to identify the causative pathogen or evaluate the antimicrobial susceptibility of the pathogen. This drawback may put patients at risk, given that inappropriate initial antimicrobial therapy for septic shock is associated with a fivefold reduction in survival (103). Combining biomarker-based monitoring with newer molecular methods, such as nucleic acid-based technologies that allow identification of specific pathogens (96), will hopefully fill this diagnostic gap. Regarding our patient, a biomarker may have revealed that she was becoming septic prior to developing hypotension, which would have enabled a timely and adequate intervention that would ideally have prevented her from entering severe sepsis.

In contrast to diagnosis, biomarkers' prognostic potential and ability to guide therapy appear to be much stronger. Compared to the APACHE or SOFA scores, immunomonitoring could both identify the high-risk group and define the fluctuating inflammatory response to provide targeted, individualized therapy. In this context, serial rather than single measurements of biomarkers appear to be the most logical approach, and such protocols have been vigorously tested in both animal models and septic patients (104). For septic patients, the concept of personalized therapy tailored to their individual immunoinflammatory status has emerged only recently. Although an exaggerated hyperinflammatory response has been implicated as the cause of early sepsis mortality, the classical features of hyper- and hypoinflammatory responses greatly overlap in this disease $(6,89)$. Post hoc statistical analysis indicated that some immunomodulators could significantly improve survival when used to treat the subpopulation of septic patients at a high risk of death (105). This approach was used with mixed success in clinical trials: Out of two studies in which an anti-TNF antibody was given to patients with a high risk of death ( judged by the biomarker IL-6), only one showed a modest survival benefit (106). The lack of consensus on how to accurately define the immunoinflammatory fingerprints in a variety of septic patients is the major hurdle slowing progress in this area. However, experimental animal models of sepsis have demonstrated that a biomarker may be used (a) to successfully direct even a nonspecific therapy such as glucocorticoids and (b) to improve survival (48).

Sepsis evolving from different sites may yield different clinical trajectories. Sepsis frequently begins with a focus of infection, such as an abscess, peritonitis, or pneumonia. To diagnose disease and predict clinical trajectory, measuring inflammatory parameters at the site of infection, rather than the plasma, may be more valuable. Studies have demonstrated that local changes indicating infection occur more quickly than do systemic alterations. For example, intraperitoneal microdialysis shows that the lactate pyruvate ratios increased rapidly after urgent laparotomy (107). Peritoneal cytokine levels after major surgery were higher than plasma levels, although this study (108) did not correlate the levels with outcome. Within the lung, upregulation of soluble triggering receptor on myeloid cells 1 in minibronchoalveolar lavage very accurately detected patients with pneumonia (92). Despite the utility of measuring local levels of the biomarkers, in some cases such an approach would be impractical and/or technically challenging; peripheral blood is usually the most easily accessible specimen for testing.

\section{Comparison of Different Prediction Paradigms}

Biomarkers could be considered useful if they perform better than traditional physiologic scoring systems. Several papers have directly compared the diagnostic accuracy of the physiologic scoring system to biomarkers (Table 3). For all of these data, the analyses were 
done by looking at the area under the curve for the receiver operator characteristic. This table indicates that the biomarkers perform as well as or better than the scoring systems.

One study (109) demonstrated that different biomarkers had varying ability to predict subsequent sepsis; IL-6 performed better than PCT, which performed better than CRP. However, another study (110) found no significant difference in the IL-6 plasma levels of postoperative patients who developed SIRS compared with those who did not, but it did find that the ratio of TNF to IL-10 was predictive. Other studies (111) have documented that PCT levels are higher in patients with severe sepsis or septic shock compared with patients with only sepsis, whereas TNF and IL-10 are better at predicting mortality.

Another large study (94) evaluated several parameters to ascertain the optimal measurements to predict sepsis mortality. The concentrations of both IL-6 and TNF-soluble receptor I predicted mortality in a univariate analysis, but in a multivariate analysis only the initial plasma concentrations of IL-6 predicted 28-day mortality, even when APACHE II and age were considered in the analysis (94). Natriuretic peptides have been proposed as biomarkers, and the plasma levels of these peptides correlate with APACHE II scores in septic patients (112). In a study that evaluated levels of brain natriuretic protein (BNP) and physiologic scores, logistic regression found that BNP and SAPS II (new simplified acute physiology score) were independent predictors of hospital mortality (113). A study of PCT levels and SOFA scores showed that both had approximately equal predictive capacity, but the SOFA score predicted outcome by day 3 after admission, whereas the PCT did not achieve strong predictive power until day 6 after admission (114).

\section{Newer Markers and Approaches}

Exhaustive work remains to be done to identify the best biomarker(s) and/or an adequate milieu for their utility. A number of new biomarker contenders have recently been reported. Pro-BNP correlates well with survival (112) and predicts mortality (113) in patients with severe sepsis and septic shock. Two other potential biomarkers, restin (115) and high mobility group box 1 (116), have attracted attention because of their atypical late surge in the course of sepsis. A kinetic study of high mobility group box 1 demonstrated that it remained persistently elevated in the plasma compared with cytokines such as IL-6, IL-8, and TNF, emphasizing this biomarker's high clinical relevance $(90,92,116)$. Matrix metalloproteinases are also elevated in septic patients, and plasma levels of their tissue inhibitors are higher in septic patients who die compared with those who survive (117). Both circulating interalpha inhibitor protein (118) and gelsolin (92) inversely correlate with outcome and disease severity in septic patients.An older marker has made a surprising entry: Upon the differentiation of sepsis from noninfectious SIRS in ICU patients, the accuracy of eosinophil count reached an area under the curve of 0.89 (92). Biomarkers do not necessarily need to be biologically active to be successful, given that low plasma levels of both selenium (119) or selenoprotein P (120) are robust predictors of outcome in critically ill.

Given the perplexing heterogeneity of possible septic scenarios, the diagnosis and prognosis of sepsis in a more homogenous setting may dramatically improve the accuracy of otherwise poor markers and may identify promising new ones. For example, circulating pro-C-type natriuretic peptide may serve as an accurate predictor of sepsis in an exclusive cohort of multiple-traumatized patients without traumatic brain injury (121). Serum amyloid A is an accurate and reliable marker for diagnosis and follow-up of neonatal sepsis and was especially useful at the onset of inflammation for the rapid diagnosis of neonatal sepsis; it performed better than CRP and PCT, which were tested in the same study (122). 
Determining severity of disease is not always clear, as demonstrated by the study of early goal-directed therapy by Rivers et al. (101). This study showed that the severity of sepsis was frequently underdiagnosed in the emergency room. SIRS criteria lack sufficient power to predict the progression of initially non-life-threatening infections (e.g., communityacquired pneumonia) to severe sepsis, septic shock, and death. To overcome these limitations, investigators (123) have employed sophisticated data analysis, such as artificial neural networks, in an attempt to better define the cohort of septic patients who are at a high risk of death after admission to the emergency room. Other investigators (124) have developed mathematical models to better predict patient trajectories: An empirically based Monte Carlo microsimulation model was able to predict hospital discharges, in-hospital deaths, and serial SOFA scores of patients with sepsis, which demonstrates that the duration of disease is a critical factor in predicting the outcomes of sepsis.

\section{THERAPEUTIC INTERVENTIONS}

As different pathogenic aspects of sepsis have been identified, different therapies have been developed in an attempt to improve survival. Table 4 lists the sepsis trials registered with http://www.clinicaltrials.gov as of February 2010. Initial attempts to neutralize mediators of the overexuberant inflammatory response by use of monoclonal antibodies against TNF $(125,126)$, IL-1 receptors (127), and or antibodies to endotoxin (128) failed to demonstrate any improvement in survival and emphasized the extreme complexity and redundant nature of the innate cytokine response during sepsis. Broader attempts to suppress the inflammatory response through the use of high-dose steroids also did not lead to any improvement in survival (129). However, a lower dose of steroid (e.g., hydrocortisone at $200 \mathrm{mg}$ per day) although it did not lead to an actual reduction in mortality—did decrease time to reversal of shock and therefore is used as an adjunctive therapy in sepsis (130). More recent potential therapies, such as a synthetic Toll-like receptor 4 antagonist, are directed at targets further upstream of the inflammatory cascade. However, a recent review (131) of the Phase II clinical trial of this drug did not show any significant decrease in mortality, although a trend toward a lower mortality rate was observed in the higher-dose group. Activated protein $\mathrm{C}$, the only FDA-approved therapy for sepsis, is targeted toward the microthrombosis that occurs during sepsis; it is hypothesized to have antiinflammatory effects as well (53). However, at this time there is no conclusive proof to this claim. Use of this therapy is described in greater detail in the section entitled Coagulation and Sepsis. Early goal-directed therapy (EGDT) is not specifically directed at the infectious and inflammatory pathophysiology of sepsis. EGDT has reduced mortality in clinical trials of severe sepsis and septic shock (132) and evolved into the Surviving Sepsis guidelines (133), which address the need for timely and active supportive care of the septic patient (Table 5). The overall goals of these guidelines are to maintain adequate organ perfusion, control infection, limit barotrauma due to mechanical ventilation, and control hyperglycemia. Other specific interventions, such as the use of low-dose steroids or activated protein C, are suggested if indicated. A recent review of multiple centers demonstrated a decrease in mortality associated with increased compliance with the guidelines (81).

\section{Acknowledgments}

The drawing skills of Brian Japp for Figure 1 are gratefully acknowledged.

\section{Glossary}

$\begin{array}{ll}\text { SIRS } & \text { systemic inflammatory response syndrome } \\ \text { TNF } & \text { tumor necrosis factor }\end{array}$




$\begin{array}{ll}\text { APC } & \text { antigen presenting cell } \\ \text { CSM } & \text { costimulatory molecule } \\ \text { DIC } & \text { disseminated intravascular coagulation } \\ \text { PT } & \text { prothrombin time } \\ \text { APTT } & \text { activated partial thromboplastin time } \\ \text { TFPI } & \text { tissue factor pathway inhibitor } \\ \text { APACHE } & \text { acute physiologic and chronic health evaluation } \\ \text { PCT } & \text { procalcitonin }\end{array}$

\section{LITERATURE CITED}

1. Martin G, Brunkhorst FM, Janes JM, Reinhart K, Sundin DP, et al. The international PROGRESS registry of patients with severe sepsis: drotrecogin alfa (activated) use and patient outcomes. Crit. Care. 2009; 13:R103. [PubMed: 19566927]

2. Benoit M, Desnues B, Mege JL. Macrophage polarization in bacterial infections. J. Immunol. 2008; 181:3733-3739. [PubMed: 18768823]

3. Alcaide P, Auerbach S, Luscinskas FW. Neutrophil recruitment under shear flow: It's all about endothelial cell rings and gaps. Microcirculation. 2009; 16:43-57. [PubMed: 18720226]

4. Urban CF, Lourido S, Zychlinsky A. How do microbes evade neutrophil killing? Cell Microbiol. 2006; 8:1687-1696. [PubMed: 16939535]

5. Le Tulzo Y, Pangault C, Gacouin A, Guilloux V, Tribut O, et al. Early circulating lymphocyte apoptosis in human septic shock is associated with poor outcome. Shock. 2002; 18:487-494. [PubMed: 12462554]

6. Hotchkiss RS, Karl IE. The pathophysiology and treatment of sepsis. N. Engl. J. Med. 2003; 348:138-150. [PubMed: 12519925]

7. Hotchkiss RS, Osmon SB, Chang KC, Wagner TH, Coopersmith CM, Karl IE. Accelerated lymphocyte death in sepsis occurs by both the death receptor and mitochondrial pathways. J. Immunol. 2005; 174:5110-5118. [PubMed: 15814742]

8. Hotchkiss RS, Swanson PE, Freeman BD, Tinsley KW, Cobb JP, et al. Apoptotic cell death in patients with sepsis, shock, and multiple organ dysfunction. Crit. Care Med. 1999; 27:1230-1251. [PubMed: 10446814]

9. Hotchkiss RS, Tinsley KW, Swanson PE, Schmieg RE Jr, Hui JJ, et al. Sepsis-induced apoptosis causes progressive profound depletion of $\mathrm{B}$ and $\mathrm{CD} 4^{+} \mathrm{T}$ lymphocytes in humans. J. Immunol. 2001; 166:6952-6963. [PubMed: 11359857]

10. Murphey ED, Lin CY, McGuire RW, Toliver-Kinsky T, Herndon DN, Sherwood ER. Diminished bacterial clearance is associated with decreased IL-12 and interferon- $\gamma$ production but a sustained proinflammatory response in a murine model of postseptic immunosuppression. Shock. 2004; 21:415-425. [PubMed: 15087817]

11. Roger PM, Hyvernat H, Breittmayer JP, Dunais B, Dellamonica J, et al. Enhanced T-cell apoptosis in human septic shock is associated with alteration of the costimulatory pathway. Eur. J. Clin. Microbiol. Infect. Dis. 2009; 28:575-584. [PubMed: 19229566]

12. Monneret G, Debard AL, Venet F, Bohe J, Hequet O, et al. Marked elevation of human circulating $\mathrm{CD} 4{ }^{+} \mathrm{CD} 25^{+}$regulatory T cells in sepsis-induced immunoparalysis. Crit. Care Med. 2003; 31:2068-2071. [PubMed: 12847405]

13. Venet F, Chung CS, Kherouf H, Geeraert A, Malcus C, et al. Increased circulating regulatory T cells $\left(\mathrm{CD} 4^{+} \mathrm{CD} 25^{+} \mathrm{CD} 127^{-}\right)$contribute to lymphocyte anergy in septic shock patients. Intensive Care Med. 2009; 35:678-686. [PubMed: 18946659] 
14. Flohe' SB, Agrawal H, Schmitz D, Gertz M, Flohe' S, Schade FU. Dendritic cells during polymicrobial sepsis rapidly mature but fail to initiate a protective Th1-type immune response. J. Leukoc. Biol. 2006; 79:473-481. [PubMed: 16365154]

15. Pelekanou A, Tsangaris I, Kotsaki A, Karagianni V, Giamarellou H, et al. Decrease of CD4 lymphocytes and apoptosis of CD14 monocytes are characteristic alterations in sepsis caused by ventilator-associated pneumonia: results from an observational study. Crit. Care. 2009; 13:R172. [PubMed: 19883512]

16. Greenwald RJ, Freeman GJ, Sharpe AH. The B7 family revisited. Annu. Rev. Immunol. 2005; 23:515-548. [PubMed: 15771580]

17. Sharpe AH, Freeman GJ. The B7-CD28 superfamily. Nat. Rev. Immunol. 2002; 2:116-126. [PubMed: 11910893]

18. Suntharalingam G, Perry MR, Ward S, Brett SJ, Castello-Cortes A, et al. Cytokine storm in a phase 1 trial of the anti-CD28 monoclonal antibody TGN1412. N. Engl. J. Med. 2006; 355:1018-1028. [PubMed: 16908486]

19. Nolan A, Weiden M, Kelly A, Hoshino Y, Hoshino S, et al. CD40 and CD80/86 act synergistically to regulate inflammation and mortality in polymicrobial sepsis. Am. J. Respir. Crit. Care Med. 2008; 177:301-308. [PubMed: 17989345]

20. Cavaillon JM, Annane D. Compartmentalization of the inflammatory response in sepsis and SIRS. J. Endotoxin Res. 2006; 12:151-170. [PubMed: 16719987]

21. Wolk K, Höflich C, Zuckermann-Becker H, Döcke WD, Volk HD, Sabat R. Reduced monocyte CD86 expression in postinflammatory immunodeficiency. Crit. Care Med. 2007; 35:458-467. [PubMed: 17204999]

22. Ward NS, Casserly B, Ayala A. The compensatory anti-inflammatory response syndrome (CARS) in critically ill patients. Clin. Chest Med. 2008; 29:617-625. [PubMed: 18954697]

23. Hotchkiss RS, Coopersmith CM, McDunn JE, Ferguson TA. The sepsis seesaw: tilting toward immunosuppression. Nat. Med. 2009; 15:496-497. [PubMed: 19424209]

24. Nolan A, Kobayashi H, Naveed B, Kelly A, Hoshino Y, et al. Differential role for CD80 and CD86 in the regulation of the innate immune response in murine polymicrobial sepsis. PLoS One. 2009; 4:e6600. [PubMed: 19672303]

25. Kiener PA, Moran-Davis P, Rankin BM, Wahl AF, Aruffo A, Hollenbaugh D. Stimulation of CD40 with purified soluble gp39 induces proinflammatory responses in human monocytes. J. Immunol. 1995; 155:4917-4925. [PubMed: 7594496]

26. Suttles J, Stout RD. Macrophage CD40 signaling: a pivotal regulator of disease protection and pathogenesis. Semin. Immunol. 2009; 21:257-264. [PubMed: 19540774]

27. Ma DY, Clark EA. The role of CD40 and CD154/CD40L in dendritic cells. Semin. Immunol. 2009; 21:265-272. [PubMed: 19524453]

28. Scott MJ, Hoth JJ, Stagner MK, Gardner SA, Peyton JC, Cheadle WG. CD40-CD154 interactions between macrophages and natural killer cells during sepsis are critical for macrophage activation and are not interferon $\gamma$ dependent. Clin. Exp. Immunol. 2004; 137:469-477. [PubMed: 15320895]

29. Gold JA, Parsey M, Hoshino Y, Hoshino S, Nolan A, et al. CD40 contributes to lethality in acute sepsis: in vivo role for CD40 in innate immunity. Infect. Immun. 2003; 71:3521-3528. [PubMed: 12761137]

30. Schwulst SJ, Grayson MH, DiPasco PJ, Davis CG, Brahmbhatt TS, et al. Agonistic monoclonal antibody against CD40 receptor decreases lymphocyte apoptosis and improves survival in sepsis. J. Immunol. 2006; 177:557-565. [PubMed: 16785553]

31. Keir ME, Butte MJ, Freeman GJ, Sharpe AH. PD-1 and its ligands in tolerance and immunity. Annu. Rev. Immunol. 2008; 26:677-704. [PubMed: 18173375]

32. Yamazaki T, Akiba H, Iwai H, Matsuda H, Aoki M, et al. Expression of programmed death 1 ligands by murine T cells and APC. J. Immunol. 2002; 169:5538-5545. [PubMed: 12421930]

33. Barber DL, Wherry EJ, Masopust D, Zhu B, Allison JP, et al. Restoring function in exhausted CD8 T cells during chronic viral infection. Nature. 2006; 439:682-687. [PubMed: 16382236] 
34. Trautmann L, Janbazian L, Chomont N, Said EA, Gimmig S, et al. Upregulation of PD-1 expression on HIV-specific $\mathrm{CD}^{+}{ }^{+} \mathrm{T}$ cells leads to reversible immune dysfunction. Nat. Med. 2006; 12:1198-1202. [PubMed: 16917489]

35. Yao S, Wang S, Zhu Y, Luo L, Zhu G, et al. PD-1 on dendritic cells impedes innate immunity against bacterial infection. Blood. 2009; 113:5811-5818. [PubMed: 19339692]

36. Huang X, Venet F, Wang YL, Lepape A, Yuan Z, et al. PD-1 expression by macrophages plays a pathologic role in altering microbial clearance and the innate inflammatory response to sepsis. Proc. Natl. Acad. Sci. USA. 2009; 106:6303-6308. [PubMed: 19332785]

37. Pinheiro da Silva F, Nizet V. Cell death during sepsis: integration of disintegration in the inflammatory response to overwhelming infection. Apoptosis. 2009; 14:509-521. [PubMed: 19199035]

38. Melino G. The sirens' song. Nature. 2001; 412:423. [PubMed: 11473313]

39. Hotchkiss RS, Strasser A, McDunn JE, Swanson PE. Cell death. N. Engl. J. Med. 2009; 361:15701583. [PubMed: 19828534]

40. Bayir H, Kagan VE. Bench-to-bedside review: Mitochondrial injury, oxidative stress and apoptosis - there is nothing more practical than a good theory. Crit. Care. 2008; 12:206. [PubMed: 18341705]

41. Wesche DE, Lomas-Neira JL, Perl M, Chung CS, Ayala A. Leukocyte apoptosis and its significance in sepsis and shock. J. Leukoc. Biol. 2005; 78:325-337. [PubMed: 15817707]

42. Hotchkiss RS, Chang KC, Grayson MH, Tinsley KW, Dunne BS, et al. Adoptive transfer of apoptotic splenocytes worsens survival, whereas adoptive transfer of necrotic splenocytes improves survival in sepsis. Proc. Natl. Acad. Sci. USA. 2003; 100:6724-6729. [PubMed: 12736377]

43. Hotchkiss RS, Nicholson DW. Apoptosis and caspases regulate death and inflammation in sepsis. Nat. Rev. Immunol. 2006; 6:813-822. [PubMed: 17039247]

44. Hotchkiss RS, Tinsley KW, Swanson PE, Grayson MH, Osborne DF, et al. Depletion of dendritic cells, but not macrophages, in patients with sepsis. J. Immunol. 2002; 168:2493-2500. [PubMed: 11859143]

45. Hemmer CJ, Vogt A, Unverricht M, Krause R, Lademann M, Reisinger EC. Malaria and bacterial sepsis: similar mechanisms of endothelial apoptosis and its prevention in vitro. Crit. Care Med. 2008; 36:2562-2568. [PubMed: 18679107]

46. Hotchkiss RS, Swanson PE, Cobb JP, Jacobson A, Buchman TG, Karl IE. Apoptosis in lymphoid and parenchymal cells during sepsis: findings in normal and T- and B-cell-deficient mice. Crit. Care Med. 1997; 25:1298-1307. [PubMed: 9267941]

47. Remick DG, Bolgos GR, Siddiqui J, Shin J, Nemzek JA. Six at six: interleukin-6 measured $6 \mathrm{~h}$ after the initiation of sepsis predicts mortality over 3 days. Shock. 2002; 17:463-467. [PubMed: 12069181]

48. Osuchowski MF, Connett J, Welch K, Granger J, Remick DG. Stratification is the key: Inflammatory biomarkers accurately direct immunomodulatory therapy in experimental sepsis. Crit. Care Med. 2009; 37:1567-1573. [PubMed: 19325479]

49. Jimenez MF, Watson RW, Parodo J, Evans D, Foster D, et al. Dysregulated expression of neutrophil apoptosis in the systemic inflammatory response syndrome. Arch. Surg. 1997; 132:1263-1270. [PubMed: 9403528]

50. Keel M, Ungethum U, Steckholzer U, Niederer E, Hartung T, et al. Interleukin-10 counterregulates proinflammatory cytokine-induced inhibition of neutrophil apoptosis during severe sepsis. Blood. 1997; 90:3356-3363. [PubMed: 9345017]

51. Taneja R, Parodo J, Jia SH, Kapus A, Rotstein OD, Marshall JC. Delayed neutrophil apoptosis in sepsis is associated with maintenance of mitochondrial transmembrane potential and reduced caspase-9 activity. Crit. Care Med. 2004; 32:1460-1469. [PubMed: 15241089]

52. Unsinger J, McDonough JS, Shultz LD, Ferguson TA, Hotchkiss RS. Sepsis-induced human lymphocyte apoptosis and cytokine production in "humanized" mice. J. Leukoc. Biol. 2009; 86:219-227. [PubMed: 19369639] 
53. Bernard GR, Vincent JL, Laterre PF, LaRosa SP, Dhainaut JF, et al. Efficacy and safety of recombinant human activated protein C for severe sepsis. N. Engl. J. Med. 2001; 344:699-709. [PubMed: 11236773]

54. Abraham E, Reinhart K, Opal S, Demeyer I, Doig C, et al. Efficacy and safety of tifacogin (recombinant tissue factor pathway inhibitor) in severe sepsis: a randomized controlled trial. J. Am. Med. Assoc. 2003; 290:238-247.

55. Nadel S, Goldstein B, Williams MD, Dalton H, Peters M, et al. Drotrecogin alfa (activated) in children with severe sepsis: a multicentre phase III randomised controlled trial. Lancet. 2007; 369:836-843. [PubMed: 17350452]

56. Jaimes F, De La Rosa G, Morales C, Fortich F, Arango C, et al. Unfractioned heparin for treatment of sepsis: a randomized clinical trial (the HETRASE Study). Crit. Care Med. 2009; 37:1185-1196. [PubMed: 19242322]

57. Warren BL, Eid A, Singer P, Pillay SS, Carl P, et al. Caring for the critically ill patient. High-dose antithrombin III in severe sepsis: a randomized controlled trial. J. Am. Med. Assoc. 2001; 286:1869-1878.

58. Warren HS, Suffredini AF, Eichacker PQ, Munford RS. Risks and benefits of activated protein C treatment for severe sepsis. N. Engl. J. Med. 2002; 347:1027-1030. [PubMed: 12324562]

59. Kushimoto S, Gando S, Saitoh D, Ogura H, Mayumi T, et al. Clinical course and outcome of disseminated intravascular coagulation diagnosed by Japanese Association for Acute Medicine criteria. Comparison between sepsis and trauma. Thromb. Haemost. 2008; 100:1099-1105. [PubMed: 19132236]

60. Adam SS, Key NS, Greenberg CS. D-dimer antigen: current concepts and future prospects. Blood. 2009; 113:2878-2887. [PubMed: 19008457]

61. Bode W. The structure of thrombin: a janus-headed proteinase. Semin. Thromb. Hemost. 2006; 32(Suppl. 1):16-31. [PubMed: 16673263]

62. Coughlin SR. Protease-activated receptors in hemostasis, thrombosis and vascular biology. J. Thromb. Haemost. 2005; 3:1800-1814. [PubMed: 16102047]

63. Di Nisio M, Middeldorp S, Buller HR. Direct thrombin inhibitors. N. Engl. J. Med. 2005; 353:1028-1040. [PubMed: 16148288]

64. Corral J, Yelamos J, Hernandez-Espinosa D, Monreal Y, Mota R, et al. Role of lipopolysaccharide and cecal ligation and puncture on blood coagulation and inflammation in sensitive and resistant mice models. Am. J. Pathol. 2005; 166:1089-1098. [PubMed: 15793289]

65. Wiedermann CJ, Hoffmann JN, Juers M, Ostermann H, Kienast J, et al. High-dose antithrombin III in the treatment of severe sepsis in patients with a high risk of death: efficacy and safety. Crit. Care Med. 2006; 34:285-292. [PubMed: 16424704]

66. Konigsberg W, Kirchhofer D, Riederer MA, Nemerson Y. The TF:VIIa complex: clinical significance, structure-function relationships and its role in signaling and metastasis. Thromb. Haemost. 2001; 86:757-771. [PubMed: 11583305]

67. Ahamed J, Versteeg HH, Kerver M, Chen VM, Mueller BM, et al. Disulfide isomerization switches tissue factor from coagulation to cell signaling. Proc. Natl. Acad. Sci. USA. 2006; 103:13932-13937. [PubMed: 16959886]

68. Bach RR, Monroe D. What is wrong with the allosteric disulfide bond hypothesis? Arterioscler. Thromb. Vasc. Biol. 2009; 29:1997-1998. [PubMed: 19923558]

69. Bogdanov VY, Balasubramanian V, Hathcock J, Vele O, Lieb M, Nemerson Y. Alternatively spliced human tissue factor: a circulating, soluble, thrombogenic protein. Nat. Med. 2003; 9:458462. [PubMed: 12652293]

70. Bajaj MS, Kuppuswamy MN, Saito H, Spitzer SG, Bajaj SP. Cultured normal human hepatocytes do not synthesize lipoprotein-associated coagulation inhibitor: evidence that endothelium is the principal site of its synthesis. Proc. Natl. Acad. Sci. USA. 1990; 87:8869-8873. [PubMed: 2247459]

71. Broze GJ, Warren L, Novotny W, Higuchi D, Girard J, Miletich J. The lipoprotein-associated coagulation inhibitor that inhibits the factor VII-tissue factor complex also inhibits factor Xa: insight into its possible mechanism of action. Blood. 1988; 71:335-343. [PubMed: 3422166] 
72. Carr C, Bild GS, Chang AC, Peer GT, Palmier MO, et al. Recombinant E. coli-derived tissue factor pathway inhibitor reduces coagulopathic and lethal effects in the baboon gram-negative model of septic shock. Circ. Shock. 1994; 44:126-137. [PubMed: 7600636]

73. de Jonge E, Dekkers PE, Creasey AA, Hack CE, Paulson SK, et al. Tissue factor pathway inhibitor dose-dependently inhibits coagulation activation without influencing the fibrinolytic and cytokine response during human endotoxemia. Blood. 2000; 95:1124-1129. [PubMed: 10666180]

74. Fukudome K, Ye X, Tsuneyoshi N, Tokunaga O, Sugawara K, et al. Activation mechanism of anticoagulant protein $\mathrm{C}$ in large blood vessels involving the endothelial cell protein $\mathrm{C}$ receptor. J. Exp. Med. 1998; 187:1029-1035. [PubMed: 9529319]

75. Stearns-Kurosawa DJ, Kurosawa S, Mollica JS, Ferrell GL, Esmon CT. The endothelial cell protein $\mathrm{C}$ receptor augments protein $\mathrm{C}$ activation by the thrombin-thrombomodulin complex. Proc. Natl. Acad. Sci. USA. 1996; 93:10212-10216. [PubMed: 8816778]

76. Marlar RA, Kleiss AJ, Griffin JH. Human protein C: inactivation of factors V and VIII in plasma by the activated molecule. Ann. N.Y. Acad. Sci. 1981; 370:303-310. [PubMed: 6791548]

77. Mosnier LO, Zlokovic BV, Griffin JH. The cytoprotective protein C pathway. Blood. 2007; 109:3161-3172. [PubMed: 17110453]

78. Xu J, Zhang X, Pelayo R, Monestier M, Ammollo CT, et al. Extracellular histones are major mediators of death in sepsis. Nat. Med. 2009; 15:1318-1321. [PubMed: 19855397]

79. Taylor FB Jr, Chang A, Esmon CT, D’Angelo A, Vigano-D’Angelo S, Blick KE. Protein C prevents the coagulopathic and lethal effects of Escherichia coli infusion in the baboon. J. Clin. Investig. 1987; 79:918-925. [PubMed: 3102560]

80. Abraham E, Laterre PF, Garg R, Levy H, Talwar D, et al. The Administration of Drotrecogin Alfa in Early Stage Severe Sepsis Study. Drotrecogin alfa (activated) for adults with severe sepsis and a low risk of death. N. Engl. J. Med. 2005; 353:1332-1341. [PubMed: 16192478]

81. Levy MM, Dellinger RP, Townsend SR, Linde-Zwirble WT, Marshall JC, et al. The Surviving Sepsis Campaign: results of an international guideline-based performance improvement program targeting severe sepsis. Crit. Care Med. 2010; 38:367-374. [PubMed: 20035219]

82. de Kleijn ED, de Groot R, Hack CE, Mulder PG, Engl W, et al. Activation of protein C following infusion of protein $\mathrm{C}$ concentrate in children with severe meningococcal sepsis and purpura fulminans: a randomized, double-blinded, placebo-controlled, dose-finding study. Crit. Care Med. 2003; 31:1839-1847. [PubMed: 12794428]

83. Fischer D, Schloesser RL, Nold-Petry CA, Nold MF, Veldman A. Protein C concentrate in preterm neonates with sepsis. Acta Paediatr. 2009; 98:1526-1529. [PubMed: 19604168]

84. Lassen MR, Davidson BL, Gallus A, Pineo G, Ansell J, Deitchman D. The efficacy and safety of apixaban, an oral, direct factor Xa inhibitor, as thromboprophylaxis in patients following total knee replacement. J. Thromb. Haemost. 2007; 5:2368-2375. [PubMed: 17868430]

85. Perzborn E, Strassburger J, Wilmen A, Pohlmann J, Roehrig S, et al. In vitro and in vivo studies of the novel antithrombotic agent BAY 59-7939—an oral, direct factor Xa inhibitor. J. Thromb. Haemost. 2005; 3:514-521. [PubMed: 15748242]

86. Laux V, Perzborn E, Kubitza D, Misselwitz F. Preclinical and clinical characteristicsofrivaroxaban: a novel, oral, direct factor Xa inhibitor. Semin. Thromb. Hemost. 2007; 33:515-523. [PubMed: 17629849]

87. Borensztajn K, Peppelenbosch MP, Spek CA. Factor Xa: at the crossroads between coagulation and signaling in physiology and disease. Trends Mol. Med. 2008; 14:429-440. [PubMed: 18774340]

88. Lavrentieva A, Kontakiotis T, Lazaridis L, Tsotsolis N, Koumis J, et al. Inflammatory markers in patients with severe burn injury. What is the best indicator of sepsis? Burns. 2007; 33:189-194. [PubMed: 17215085]

89. Remick DG. Cytokine therapeutics for the treatment of sepsis: Why has nothing worked? Curr. Pharm. Des. 2003; 9:75-82. [PubMed: 12570677]

90. Marshall JC, Reinhart K. Biomarkers of sepsis. Crit. Care Med. 2009; 37:2290-2298. [PubMed: 19487943]

91. Becker KL, Snider R, Nylen ES. Procalcitonin assay in systemic inflammation, infection, and sepsis: clinical utility and limitations. Crit. Care Med. 2008; 36:941-952. [PubMed: 18431284] 
92. Opal SM, LaRosa SP. Year in review 2008: Critical care-sepsis. Crit. Care. 2009; 13:224. [PubMed: 19886974]

93. Remick DG. Pathophysiology of sepsis. Am. J. Pathol. 2007; 170:1435-1444. [PubMed: 17456750]

94. Oberholzer A, Souza SM, Tschoeke SK, Oberholzer C, Abouhamze A, et al. Plasma cytokine measurements augment prognostic scores as indicators of outcome in patients with severe sepsis. Shock. 2005; 23:488-493. [PubMed: 15897799]

95. Osuchowski MF, Welch K, Siddiqui J, Remick DG. Circulating cytokine/inhibitor profiles reshape the understanding of the SIRS/CARS continuum in sepsis and predict mortality. J. Immunol. 2006; 177:1967-1974. [PubMed: 16849510]

96. Mancini N, Carletti S, Ghidoli N, Cichero P, Burioni R, Clementi M. The era of molecular and other non-culture-based methods in diagnosis of sepsis. Clin. Microbiol. Rev. 2010; 23:235-251. [PubMed: 20065332]

97. Flohe S, Scholz M. HLA-DR monitoring in the intensive care unit-more than a tool for the scientist in the laboratory? Crit. Care Med. 2009; 37:2849-2850. [PubMed: 19865013]

98. Pachot A, Cazalis MA, Venet F, Turrel F, Faudot C, et al. Decreased expression of the fractalkine receptor CX3CR1 on circulating monocytes as new feature of sepsis-induced immunosuppression. J. Immunol. 2008; 180:6421-6429. [PubMed: 18424766]

99. Icardi M, Erickson Y, Kilborn S, Stewart B, Grief B, Scharnweber G. CD64 index provides simple and predictive testing for detection and monitoring of sepsis and bacterial infection in hospital patients. J. Clin. Microbiol. 2009; 47:3914-3919. [PubMed: 19846647]

100. Becchi C, Pillozzi S, Fabbri LP, Al MM, Cacciapuoti C, et al. The increase of endothelial progenitor cells in the peripheral blood: a new parameter for detecting onset and severity of sepsis. Int. J. Immunopathol. Pharmacol. 2008; 21:697-705. [PubMed: 18831938]

101. Rivers E, Nguyen B, Havstad S, Ressler J, Muzzin A, et al. Early goal-directed therapy in the treatment of severe sepsis and septic shock. N. Engl. J. Med. 2001; 345:1368-1377. [PubMed: 11794169]

102. Kumar A, Roberts D, Wood KE, Light B, Parrillo JE, et al. Duration of hypotension before initiation of effective antimicrobial therapy is the critical determinant of survival in human septic shock. Crit. Care Med. 2006; 34:1589-1596. [PubMed: 16625125]

103. Kumar A, Ellis P, Arabi Y, Roberts D, Light B, et al. Initiation of inappropriate antimicrobial therapy results in a fivefold reduction of survival in human septic shock. Chest. 2009; 136:12371248. [PubMed: 19696123]

104. Schuetz P, Christ-Crain M, Muller B. Biomarkers to improve diagnostic and prognostic accuracy in systemic infections. Curr. Opin. Crit. Care. 2007; 13:578-585. [PubMed: 17762239]

105. Eichacker PQ, Parent C, Kalil A, Esposito C, Cui X, et al. Risk and the efficacy of antiinflammatory agents: retrospective and confirmatory studies of sepsis. Am. J. Respir. Crit. Care Med. 2002; 166:1197-1205. [PubMed: 12403688]

106. Ventetuolo CE, Levy MM. Biomarkers: diagnosis and risk assessment in sepsis. Clin. Chest Med. 2008; 29:591-603. [PubMed: 18954695]

107. Verdant CL, Chierego M, De Moor V, Chamlou R, Creteur J, et al. Prediction of postoperative complications after urgent laparotomy byintraperitoneal microdialysis:apilot study. Ann. Surg. 2006; 244:994-1002. [PubMed: 17122625]

108. Jansson K, Redler B, Truedsson L, Magnuson A, Matthiessen P, et al. Intraperitoneal cytokine response after major surgery: higher postoperative intraperitoneal versus systemic cytokine levels suggest the gastrointestinal tract as the major source of the postoperative inflammatory reaction. Am. J. Surg. 2004; 187:372-377. [PubMed: 15006565]

109. Deis JN, Creech CB, Estrada CM, Abramo TJ. Procalcitonin as a marker of severe bacterial infection in children in the emergency department. Pediatr. Emerg. Care. 2010; 26:51-60. [PubMed: 20065834]

110. Dimopoulou I, Armaganidis A, Douka E, Mavrou I, Augustatou C, et al. Tumor necrosis factor a (TNFa) and interleukin-10 are crucial mediators in postoperative systemic inflammatory response and determine the occurrence of complications after major abdominal surgery. Cytokine. 2007; 37:55-61. [PubMed: 17428673] 
111. Heper Y, Akalin EH, Mistik R, Akgoz S, Tore O, et al. Evaluation of serum C-reactive protein, procalcitonin, tumor necrosis factor $\mathrm{a}$, and interleukin-10 levels as diagnostic and prognostic parameters in patients with community-acquired sepsis, severe sepsis, and septic shock. Eur. J. Clin. Microbiol. Infect. Dis. 2006; 25:481-491. [PubMed: 16896829]

112. Brueckmann M, Huhle G, Lang S, Haase KK, Bertsch T, et al. Prognostic value of plasma Nterminal pro-brain natriuretic peptide in patients with severe sepsis. Circulation. 2005; 112:527534. [PubMed: 16027260]

113. Varpula M, Pulkki K, Karlsson S, Ruokonen E, Pettila V. Predictive value of N-terminal probrain natriuretic peptide in severe sepsis and septic shock. Crit. Care Med. 2007; 35:1277-1283. [PubMed: 17414731]

114. Dahaba AA, Hagara B, Fall A, Rehak PH, List WF, Metzler H. Procalcitonin for early prediction of survival outcome in postoperative critically ill patients with severe sepsis. Br. J. Anaesth. 2006; 97:503-508. [PubMed: 16849384]

115. Sunden-Cullberg J, Nystrom T, Lee ML, Mullins GE, Tokics L, et al. Pronounced elevation of resistin correlates with severity of disease in severe sepsis and septic shock. Crit. Care Med. 2007; 35:1536-1542. [PubMed: 17452927]

116. Sunden-Cullberg J, Norrby-Teglund A, Rouhiainen A, Rauvala H, Herman G, et al. Persistent elevation of high mobility group box 1 protein (HMGB1) in patients with severe sepsis and septic shock. Crit. Care Med. 2005; 33:564-573. [PubMed: 15753748]

117. Lorente L, Martin MM, Sole-Violan J, Blanquer J, Paramo JA. Matrix metalloproteinases and their inhibitors as biomarkers of severity in sepsis. Crit. Care. 2010; 14:402. [PubMed: 20092609]

118. Opal SM, Lim YP, Siryaporn E, Moldawer LL, Pribble JP, et al. Longitudinal studies of interalpha inhibitor proteins in severely septic patients: a potential clinical marker and mediator of severe sepsis. Crit. Care Med. 2007; 35:387-392. [PubMed: 17205024]

119. Sakr Y, Reinhart K, Bloos F, Marx G, Russwurm S, et al. Time course and relationship between plasma selenium concentrations, systemic inflammatory response, sepsis, and multiorgan failure. Br. J. Anaesth. 2007; 98:775-784. [PubMed: 17478454]

120. Hollenbach B, Morgenthaler NG, Struck J, Alonso C, Bergmann A, et al. New assay for the measurement of selenoprotein $\mathrm{P}$ as a sepsis biomarker from serum. J. Trace Elem. Med. Biol. 2008; 22:24-32. [PubMed: 18319137]

121. Bahrami S, Pelinka L, Khadem A, Maitzen S, Hawa G, et al. Circulating NT-proCNP predicts sepsis in multiple-traumatized patients without traumatic brain injury. Crit. Care Med. 2010; 38:161-166. [PubMed: 19730251]

122. Cetinkaya M, Ozkan H, Koksal N, Celebi S, Hacimustafaoglu M. Comparison of serum amyloid A concentrations with those of C-reactive protein and procalcitonin in diagnosis and follow-up of neonatal sepsis in premature infants. J. Perinatol. 2009; 29:225-231. [PubMed: 19078972]

123. Jaimes F, Farbiarz J, Alvarez D, Martinez C. Comparison between logistic regression and neural networks to predict death in patients with suspected sepsis in the emergency room. Crit. Care. 2005; 9:R150-R156. [PubMed: 15774048]

124. Saka G, Kreke JE, Schaefer AJ, Chang CC, Roberts MS, Angus DC. Use of dynamic microsimulation to predict disease progression in patients with pneumonia-related sepsis. Crit. Care. 2007; 11:R65. [PubMed: 17570835]

125. Fisher CJ Jr. Agosti JM, Opal SM, Lowry SF, Balk RA, et al. Treatment of septic shock with the tumor necrosis factor receptor:Fc fusion protein. The Soluble TNF Receptor Sepsis Study Group. N. Engl. J. Med. 1996; 334:1697-1702. [PubMed: 8637514]

126. Abraham E, Wunderink R, Silverman H, Perl TM, Nasraway S, et al. Efficacy and safety of monoclonal antibody to human tumor necrosis factor $a$ in patients with sepsis syndrome. A randomized, controlled, double-blind, multicenter clinical trial. TNF-a MAb Sepsis Study Group. J. Am. Med. Assoc. 1995; 273:934-941.

127. Fisher CJ Jr, Dhainaut JF, Opal SM, Pribble JP, Balk RA, et al. Recombinant human interleukin 1 receptor antagonist in the treatment of patients with sepsis syndrome. Results from a randomized, double-blind, placebo-controlled trial. Phase III rhIL-1ra Sepsis Syndrome Study Group. J. Am. Med. Assoc. 1994; 271:1836-1843. 
128. Ziegler EJ, Fisher CJ Jr, Sprung CL, Straube RC, Sadoff JC, et al. Treatment of gram-negative bacteremia and septic shock with HA-1A human monoclonal antibody against endotoxin. A randomized, double-blind, placebo-controlled trial. The HA-1A Sepsis Study Group. N. Engl. J. Med. 1991; 324:429-436. [PubMed: 1988827]

129. Bone RC, Fisher CJ Jr, Clemmer TP, Slotman GJ, Metz CA, Balk RA. A controlled clinical trial of high-dose methylprednisolone in the treatment of severe sepsis and septic shock. N. Engl. J. Med. 1987; 317:653-658. [PubMed: 3306374]

130. Annane D, Bellissant E, Bollaert PE, Briegel J, Confalonieri M, et al. Corticosteroids in the treatment of severe sepsis and septic shock in adults: a systematic review. J. Am. Med. Assoc. 2009; 301:2362-2375.

131. Tidswell M, Tillis W, Larosa SP, Lynn M, Wittek AE, et al. Phase 2 trial of eritoran tetrasodium (E5564), a Toll-like receptor 4 antagonist, in patients with severe sepsis. Crit. Care Med. 2010; 38:72-83. [PubMed: 19661804]

132. Rivers E, Nguyen B, Havstad S, Ressler J, Muzzin A, et al. Early Goal-Directed Therapy Collaborative Group. Early goal-directed therapy in the treatment of severe sepsis and septic shock. New Engl. J. Med. 2001; 345:1368-1377. [PubMed: 11794169]

133. Dellinger RP, Levy MM, Carlet JM, Bion J, Parker MM, et al. Surviving Sepsis Campaign: international guidelines for management of severe sepsis and septic shock. Crit. Care Med. 2008; 36:296-327. [PubMed: 18158437]

134. Kennedy AD, DeLeo FR. Neutrophil apoptosis and the resolution of infection. Immunol. Res. 2009; 43:25-61. [PubMed: 19066741]

135. Bone RC, Balk RA, Cerra FB, Dellinger RP, Fein AM, et al. Definitions for sepsis and organ failure and guidelines for the use of innovative therapies in sepsis. The ACCP/SCCM Consensus Conference Committee. American CollegeofChest Physicians/Society of Critical Care Medicine. Chest. 1992; 101:1644-1655. [PubMed: 1303622]

136. Morgenthaler NG, Struck J, Christ-Crain M, Bergmann A, Muller B. Pro-atrial natriuretic peptide is a prognostic marker in sepsis, similar to the APACHE II score: an observational study. Crit. Care. 2005; 9:R37-R45. [PubMed: 15693965]

137. Christ-Crain M, Morgenthaler NG, Struck J, Harbarth S, Bergmann A, Muller B. Mid-regional proadrenomedullin as a prognostic marker in sepsis: an observational study. Crit. Care. 2005; 9:R816-R824. [PubMed: 16356231]

138. Hoffmann U, Bertsch T, Dvortsak E, Liebetrau C, Lang S, et al. Matrix-metalloproteinases and their inhibitors are elevated in severe sepsis: prognostic value of TIMP-1 in severe sepsis. Scand. J. Infect. Dis. 2006; 38:867-872. [PubMed: 17008230]

139. Rey C, Los Arcos M, Concha A, Medina A, Prieto S, et al. Procalcitonin and C-reactive protein as markers of systemic inflammatory response syndrome severity in critically ill children. Intensive Care Med. 2007; 33:477-484. [PubMed: 17260130] 


\section{SUMMARY POINTS}

1. Sepsis is a complex, dynamic disease in which aspects of the inflammatory response become dysregulated. For a given patient, it is too simplistic to characterize the dysregulation as hyperinflammatory or immunosuppressive.

2. Both apoptosis and necrosis occur during the septic response, and a portion of the dysregulated septic response occurs when the wrong cells die at the wrong time.

3. CSMs are a key regulatory point in innate-adaptive interactions during sepsis and may provide a specific target for regulation of the adaptive response.

4. Coagulopathy frequently accompanies sepsis and increases in severity as multiple organ failure and septic shock develop. Anticoagulants alone have little impact on mortality, except in subpopulations who have severe sepsis and a high risk of death.

5. Multiple new therapies currently being evaluated include the use of biomarkers to direct appropriate therapy to individual patients. 


\section{FUTURE ISSUES}

1. Manipulation of CSM activity by use of blocking antibodies, or selective use of agents such as TLR agonists that upregulate specific CSMs on APCs, is needed in order to study the effect of modulation of the adaptive immune response on the pathophysiology of sepsis.

2. Testing of new Factor Xa inhibitors in sepsis models and high-throughput screening approaches to identify new anticoagulants are needed.

3. Identification of patient subpopulations with shared biomarkers, cell markers, coagulation status, and comorbidities is necessary to better tailor therapeutic regimens to individuals. 


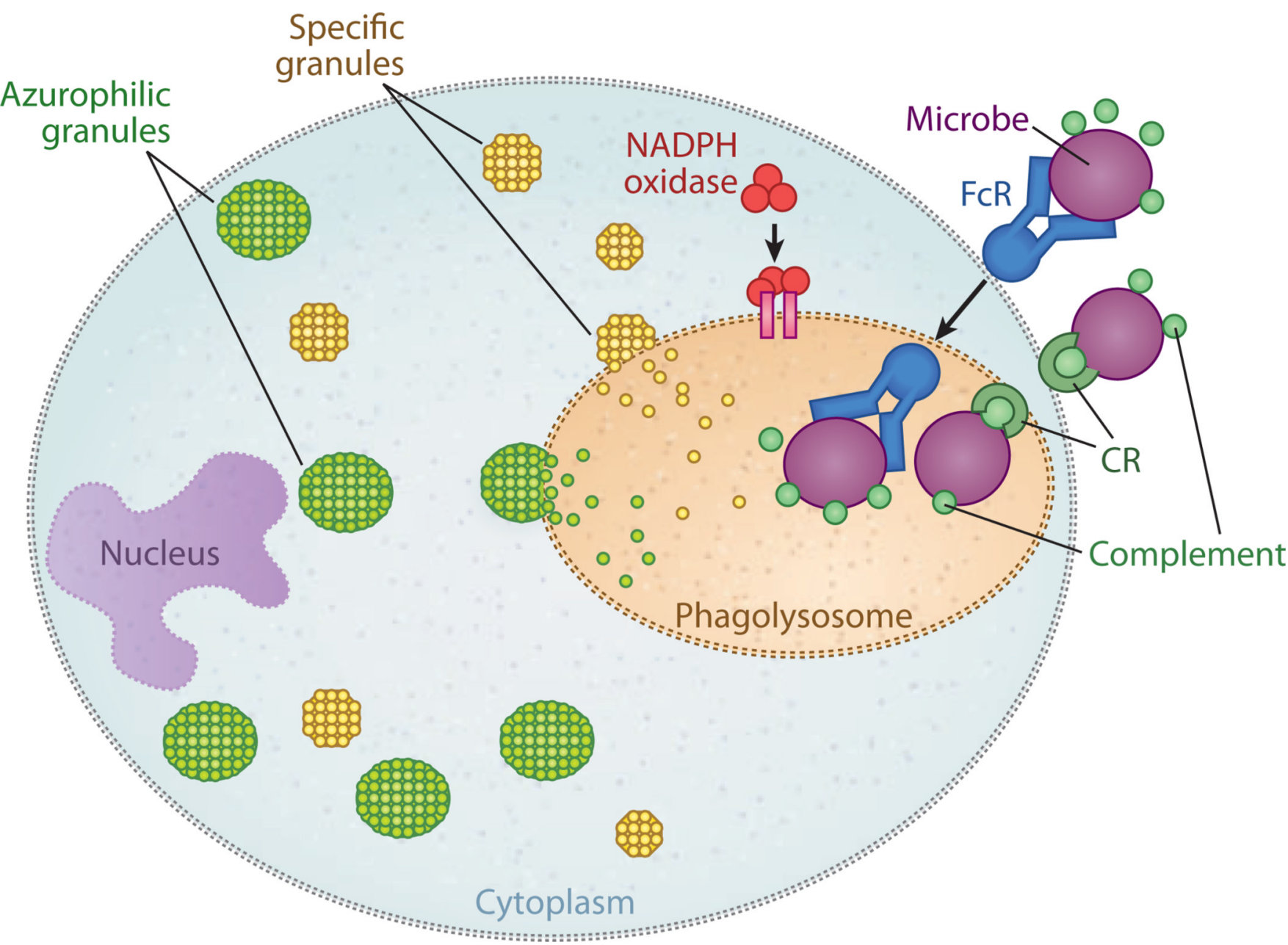

Figure 1.

Mechanisms of phagocytic-cell destruction of bacteria. Phagocytic cells such as neutrophils and macrophages are responsible for the clearance of pathogens from the body.

Opsonization is the binding of antibodies and complement fragments to components on a bacterium. The antibodies bind to $\mathrm{Fc}$ receptors (FcRs) or complement receptors (CRs) on the surface of the phagocytic cell. After binding, the bacterium is taken into the cytoplasm; the membrane vacuole containing the phagocytosed bacteria is known as the phagosome. Fusion of the phagosome cytoplasmic granules such as specific granules (yellow) and azurophilic granules (green) forms the phagolysosome. Reactive oxygen intermediates are produced through the activity of NADPH oxidase, a complex of seven proteins. Adapted from Reference 134. 


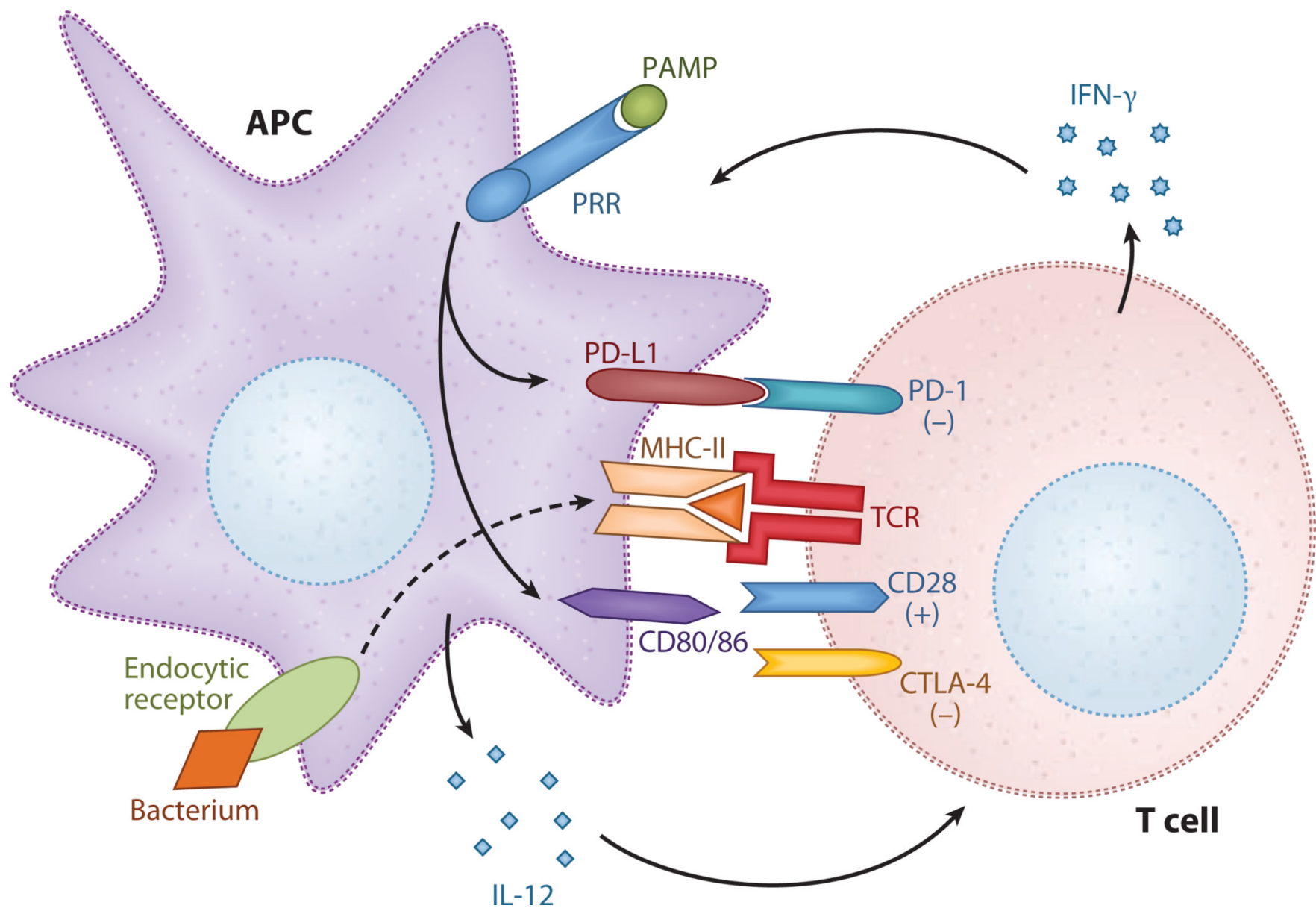

Figure 2.

Costimulatory molecules (CSMs). Antigen presenting cells (APCs) detect infection through the binding of pathogen-associated molecular patterns (PAMPs) to pattern-recognition receptors (PRRs), as well as the phagocytosis of bacteria. Interleukin (IL)-12 is released, and expression of the CSMs (CD80, CD86, and PD-L1) is upregulated. These CSMs bind to corresponding $\mathrm{T}$ cell ligands, provided that the second signal as antigen is presented in the context of the major histocompatibility complex (MHC). CD80/86 binds to CD28, resulting in $\mathrm{T}$ cell activation and proliferation, and PD-L1:PD-1 interaction leads to T cell anergy and apoptosis. Ligation of cytotoxic T lymphocyte-associated antigen (CTLA)-4 expressed on previously activated $\mathrm{T}$ cells by $\mathrm{CD} 80 / 86$ provides a negative signal that regulates the degree of $\mathrm{T}$ cell activity. Interferon (IFN)- $\gamma$ is released by the $\mathrm{T}$ cell-activating phagocytic cells to kill intracellular bacteria. 


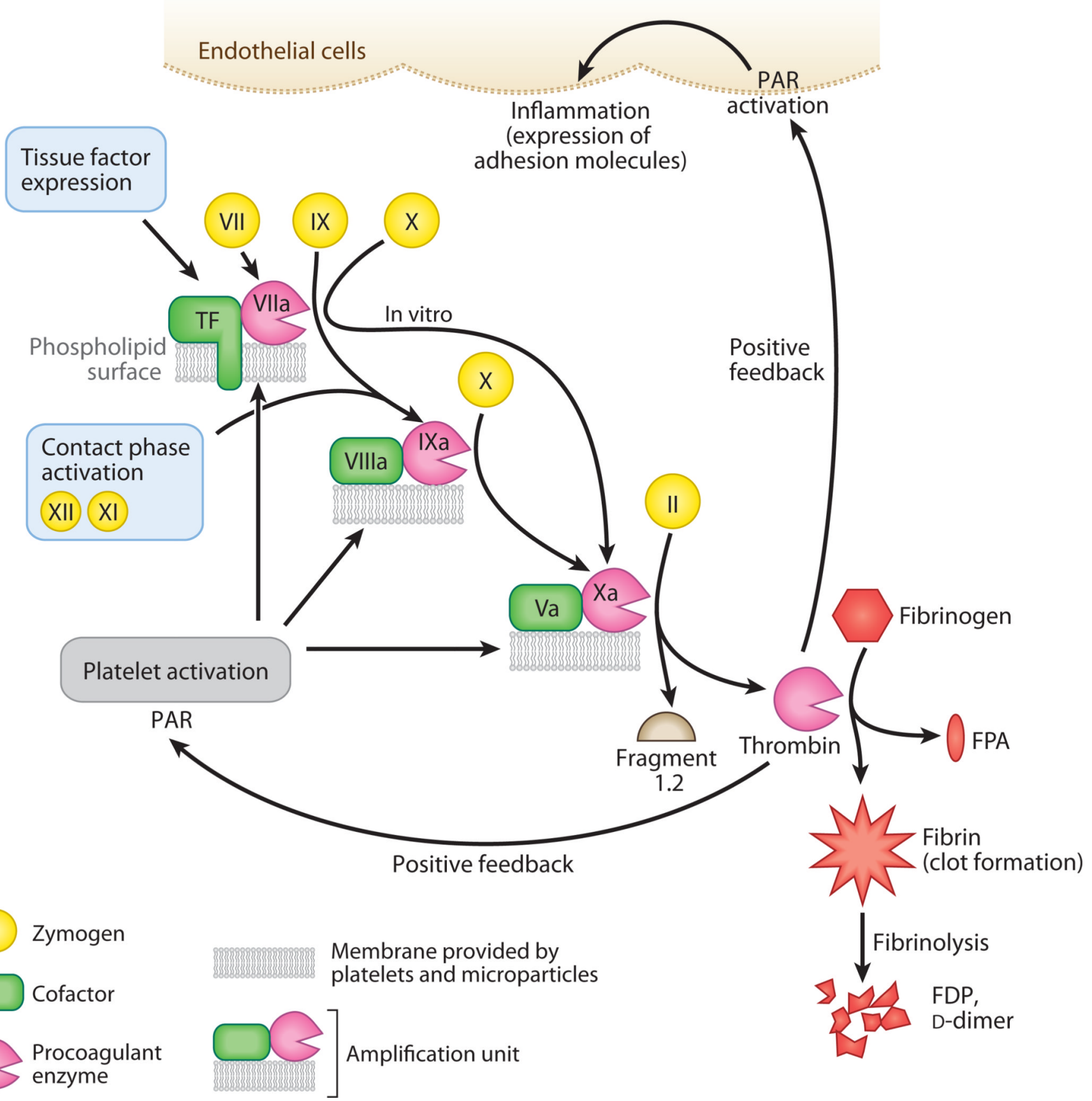

Figure 3.

The formation of a clot. The coagulation cascade features a simple amplification unit that is repeated several times: A cofactor protein (green) binds to an enzyme (pink) on a phospholipid surface. This triumvirate complex is recognized by a circulating zymogen precursor (yellow). After a brief interaction, the complexed enzyme cleaves the zymogen and activates it. This new enzyme is incorporated into the next amplification unit for activation of the next precursor molecule. The tissue factor-Factor VIIa-membrane complex begins in vivo coagulation when tissue factor is exposed to blood components after injury. Factors XII and XI begin the contact phase-activation (intrinsic) pathway. Platelets provide the majority of phospholipid surfaces to support coagulation. Prothrombin (Factor II) is the 
precursor to thrombin, the final enzyme of the cascade, which releases Fragment 1.2 and thrombin during activation. Thrombin removes fibrinopeptides from fibrinogen, forming fibrin. When fibrin oligomerizes and is cross-linked, it provides surfaces for the fibrinolytic pathway, which comprises another set of activators and enzymes that cleave the clot and release fragments [fibrin degradation products (FDPs), $\mathrm{D}$-dimers] into the circulation. Thrombin also acts in a proinflammatory manner by activating protease-activated receptors (PARs) on platelets and endothelial cells. Abbreviation: FPA, fibrinopeptide A. 


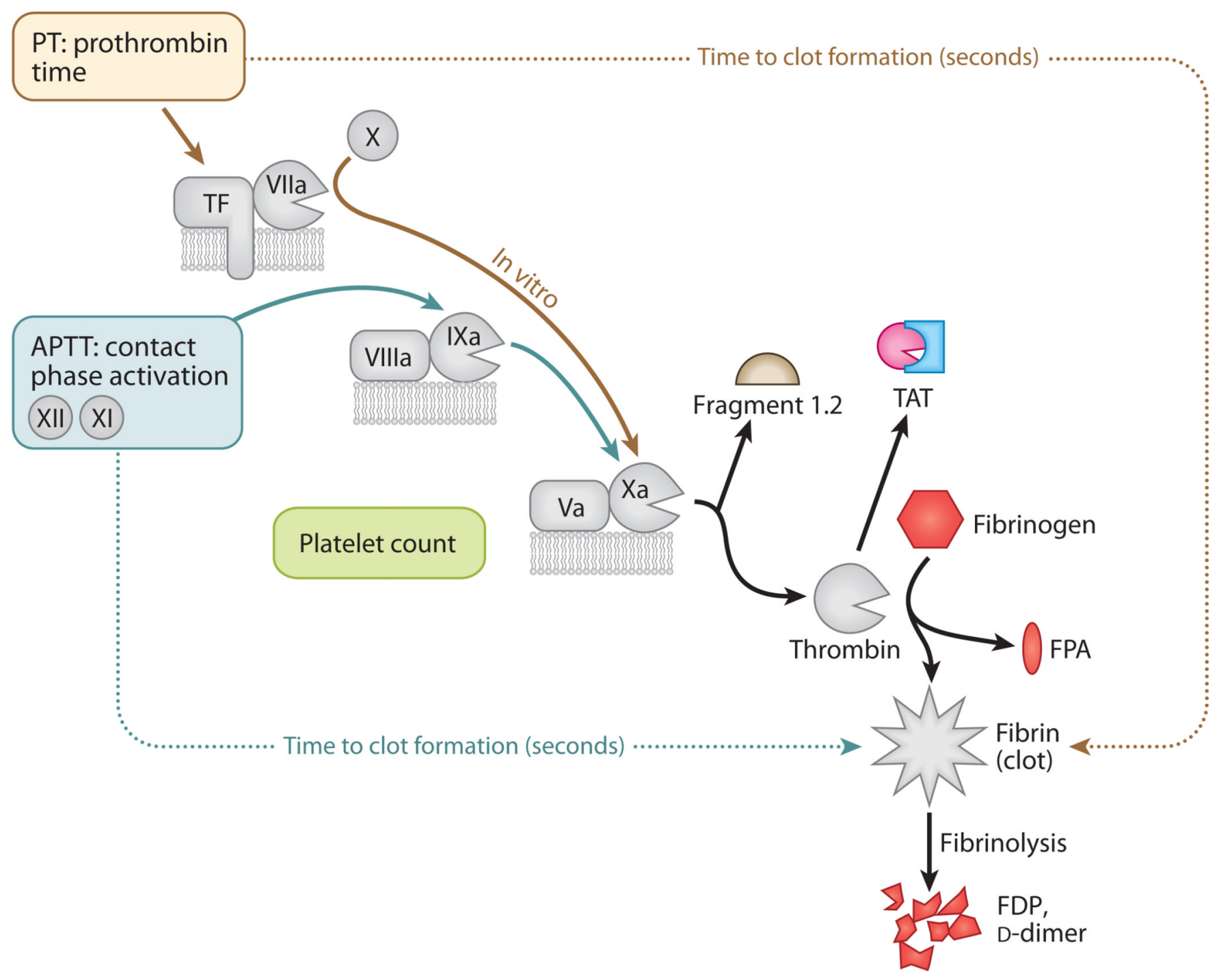

Figure 4.

Common tests in coagulation (colored entities). Steps discussed in previous figures are in gray. The prothrombin time (PT) is the number of seconds required to make a clot starting from the tissue factor (TF)-Factor VIIa-phospholipid unit. The activated partial thromboplastin time (APTT) is the number of seconds required to make a clot starting from the contact activation pathway. It is a partial clotting time because TF is not present. Both pathways merge at Factor Xa, which forms an amplification unit with Factor Va and lipid. Inhibitors of Factor Xa block the amplification unit and prevent thrombin formation. Tests are available to measure the presence of prothrombin Fragment 1.2 generated during thrombin production, the inactive thrombin-antithrombin complex (TAT), fibrinopeptide A (FPA) released during formation of fibrin, and chunks of cross-linked fibrin released during fibrinolysis of the clots [fibrin degradation products (FDPs), D-dimers]. 


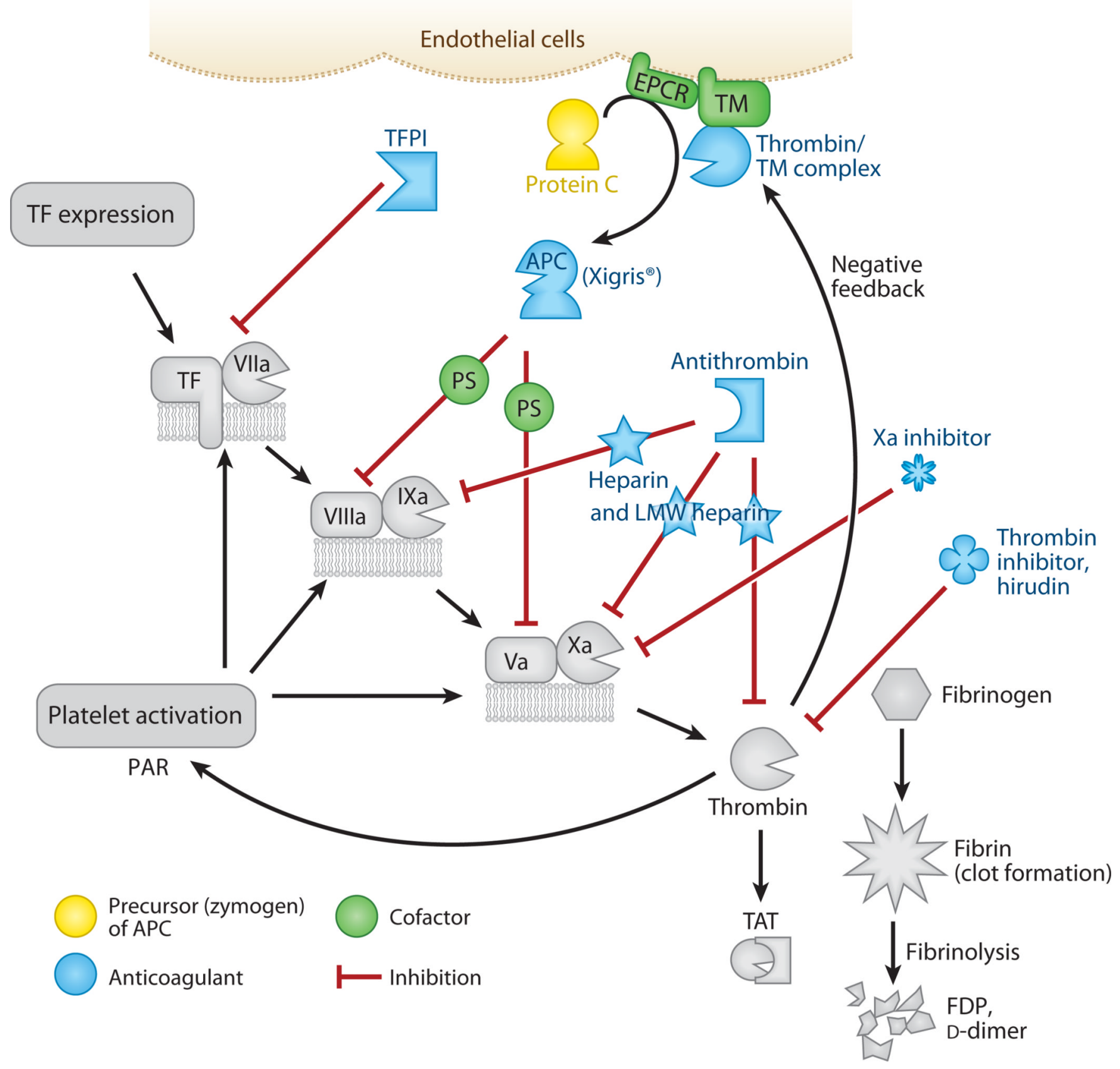

Figure 5.

The regulation of clot formation (colored entities). Steps discussed in previous figures are in gray. Regulation checkpoints during coagulation include tissue factor (TF), Factors VIIIa and $\mathrm{Va}$, and Factor Xa. If these are inhibited, then thrombin production essentially stops. Tissue factor pathway inhibitor (TFPI) blocks the TF pathway. The protein $\mathrm{C}$ pathway blocks Factors VIIIa and Va. This pathway creates the activated protein C (APC) enzyme by the combined contributions of the endothelial protein $\mathrm{C}$ receptor (EPCR), thrombin, and thrombomodulin (TM) on cell surfaces. With the help of protein S (PS), APC cleaves the VIIIa and Va cofactors, which slows clotting by orders of magnitude. The drug Xigris ${ }^{\circledR}$ is recombinant human APC and is effective in patients with severe sepsis. Antithrombin is the 
natural inhibitor of several coagulation enzymes, including Factors IXa and Xa and thrombin. Its activity is accelerated by heparin and becomes specific for Factor Xa with lowmolecular-weight (LMW) heparin. Hirudin is derived from leeches and inhibits only thrombin. Dysfunctional coagulation is common in sepsis patients, and the challenge is to prevent clot formation without increasing the risk of bleeding. Abbreviations: FDP, fibrin degradation product; PAR, protease-activated receptor; TAT, thrombin-antithrombin complex. 
Table 1

Criteria for the systemic inflammatory response syndrome (SIRS) ${ }^{a}$

\begin{tabular}{l|l}
\hline Criterion & Value \\
\hline Temperature & $>38^{\circ} \mathrm{C}$ or $<36^{\circ} \mathrm{C}$ \\
\hline Heart rate & $>90$ beats per minute \\
\hline Respiratory rate & $>20$ or $\mathrm{PaCO}_{2}<32 \mathrm{~mm} \mathrm{Hg}$ \\
\hline White blood cell count & $>12 \mathrm{~K}$ or $<4 \mathrm{~K} \mathrm{~mm}^{-3}$, or $>10 \%$ bands \\
\hline
\end{tabular}

a For a diagnosis of SIRS to be made, two of the four criteria need to be present. Data from Reference 135. 
Table 2

Tests that monitor coagulation and/or fibrinolysis ${ }^{a}$

\begin{tabular}{|c|c|c|}
\hline Test & What it measures & What it means in sepsis \\
\hline PT (s) & $\begin{array}{l}\text { Monitors Factors VII, X, V, II (tissue factor } \\
\text { pathway) and fibrinogen; functional assay }\end{array}$ & $\begin{array}{l}\text { Prolongation means either depletion of coagulation } \\
\text { factors (uncompensated DIC) and/or effect of } \\
\text { therapeutic anticoagulant }\end{array}$ \\
\hline INR & $\begin{array}{l}\text { Calculated value; PT normalized to a standardized } \\
\text { value for each thromboplastin reagent }\end{array}$ & $\begin{array}{l}\text { INR permits comparison of PT results from different } \\
\text { laboratories and different thromboplastin reagents }\end{array}$ \\
\hline $\operatorname{APTT}(s)$ & $\begin{array}{l}\text { Monitors Factors XII, XI, IX, VIII, X, V, II, and } \\
\text { fibrinogen; functional assay }\end{array}$ & $\begin{array}{l}\text { Prolongation means either depletion of coagulation } \\
\text { factors (uncompensated DIC) and/or effect of } \\
\text { therapeutic anticoagulant }\end{array}$ \\
\hline $\begin{array}{l}\text { Platelet counts } \\
\left(\text { per } \mathrm{mm}^{3}\right)\end{array}$ & $\begin{array}{l}\text { Number of circulating platelets; counts drop in } \\
\text { DIC due to increased consumption }\end{array}$ & $\begin{array}{l}\text { Counts }<30,000-50,000 \mathrm{~mm}^{-3} \text { mean imminent danger } \\
\text { of hemorrhage and will increase hemorrhagic risk of } \\
\text { anticoagulants }\end{array}$ \\
\hline $\begin{array}{l}\text { Fibrinogen } \\
\left(\mathrm{g} \mathrm{dl}^{-1}\right)\end{array}$ & $\begin{array}{l}\text { The precursor of fibrin and an acute phase } \\
\text { reactant; made in the liver; functional and } \\
\text { protein-based assays available }\end{array}$ & $\begin{array}{l}\text { Reduced level may mean compromised hemostasis; } \\
\text { normal level does not rule out DIC, especially in } \\
\text { inflammatory conditions }\end{array}$ \\
\hline FDPs & $\begin{array}{l}\text { Heterogeneous fragments of cross-linked fibrin } \\
\text { released during degradation of clots by plasmin } \\
\text { and fibrinolytic pathway; immunoassay }\end{array}$ & $\begin{array}{l}\text { Levels in DIC are generally much higher than in } \\
\text { patients with deep vein thrombosis }\end{array}$ \\
\hline D-dimer & $\begin{array}{l}\text { Fibrin fragments released during fibrinolysis; } \\
\text { D-dimer requires presence of both thrombin and } \\
\text { plasmin. Variability between test methods due to } \\
\text { heterogeneity of fragments and assay antibodies }\end{array}$ & $\begin{array}{l}\text { Elevated levels mean both coagulation and fibrinolysis } \\
\text { have occurred; generally reflect DIC severity, except for } \\
\text { severe afibrinogenemia }\end{array}$ \\
\hline Protein C & $\begin{array}{l}\text { Precursor (zymogen) form of activated protein } \mathrm{C} \text {; } \\
\text { circulates in plasma and is produced mainly by } \\
\text { the liver; functional and immunobased assays } \\
\text { are available }\end{array}$ & Decreased levels correlate with poorer prognosis in sepsis \\
\hline Bleeding time & $\begin{array}{l}\text { Excellent in vivo test for primary hemostasis; } \\
\text { functional assay }\end{array}$ & $\begin{array}{l}\text { Prolonged bleeding time means the patient has } \\
\text { compromised primary hemostasis }\end{array}$ \\
\hline Fibrinopeptide A & $\begin{array}{l}\text { Released from fibrinogen by thrombin activity; } \\
\text { measured by immunoassay }\end{array}$ & $\begin{array}{l}\text { Increased when coagulation activated; test very } \\
\text { susceptible to false elevations, such as activation during } \\
\text { phlebotomy }\end{array}$ \\
\hline Fragment 1.2 & $\begin{array}{l}\text { Fragment released from prothrombin precursor } \\
\text { during enzymatic formation of thrombin; } 1 \mathrm{~mol} \\
\text { of Fragment } 1.2=1 \mathrm{~mol} \text { thrombin; measured by } \\
\text { immunoassay }\end{array}$ & $\begin{array}{l}\text { Increased when coagulation activated; test very } \\
\text { susceptible to false elevations, such as activation during } \\
\text { phlebotomy }\end{array}$ \\
\hline TAT & $\begin{array}{l}\text { When antithrombin inactivates thrombin, the } \\
\text { reaction produces stable TAT complex; } \\
\text { measured by immunoassay }\end{array}$ & $\begin{array}{l}\text { Increased TAT means increased thrombin generation; } \\
\text { also susceptible to false elevations }\end{array}$ \\
\hline
\end{tabular}

${ }^{a}$ Abbreviations: APTT, activated partial thromboplastin time; DIC, disseminated intravascular coagulation; FDPs, fibrin degradation products; INR, international normalized ratio; PT, prothrombin time; TAT, thrombin-antithrombin complex. 


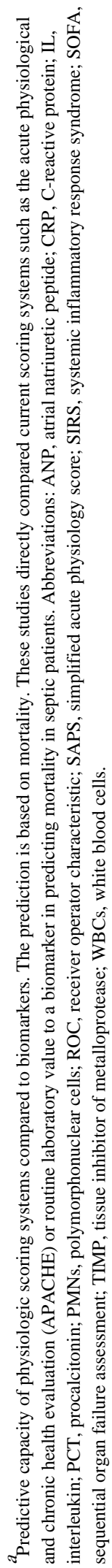

\begin{tabular}{|c|c|c|c|c|c|c|c|c|c|}
\hline \multirow{6}{*}{ 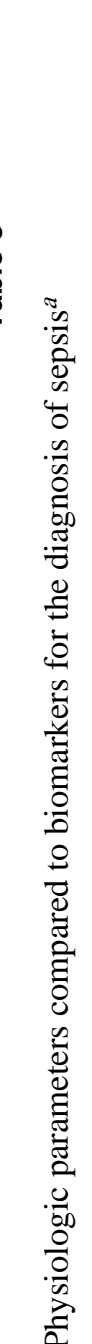 } & 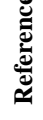 & $\infty$ & $\stackrel{\overbrace{}}{\dddot{2}}$ & $\hat{m}$ & $\stackrel{2}{\beth}$ & $\Xi$ & $\stackrel{\infty}{\stackrel{\infty}{\sim}}$ & ફे & 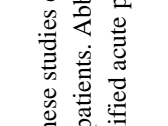 \\
\hline & U. & 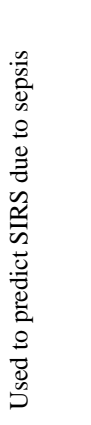 & 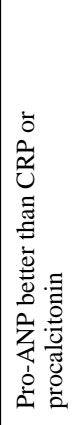 & 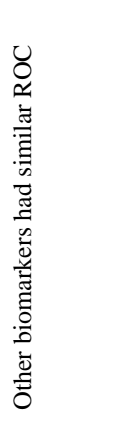 & 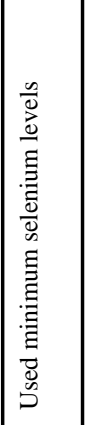 & 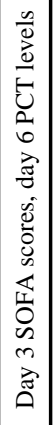 & & 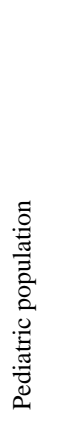 & 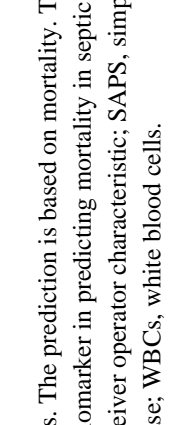 \\
\hline & 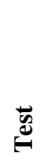 & 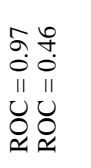 & $\begin{array}{l}\infty \\
\infty \\
0 \\
11 \\
0 \\
0 \\
\propto\end{array}$ & 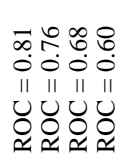 & $\begin{array}{l}0 \\
0 \\
0 \\
0 \\
11 \\
0 \\
0 \\
\approx\end{array}$ & $\begin{array}{l}8 \\
8 \\
0 \\
11 \\
0 \\
\approx\end{array}$ & $\begin{array}{ll}\infty & \Re \\
0 & 0 \\
0 & 0 \\
\| 1 & \| 1 \\
0 & 0 \\
\approx & \approx\end{array}$ & 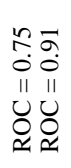 & \\
\hline & 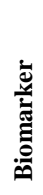 & 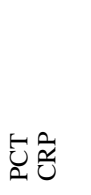 & 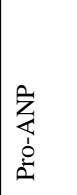 & 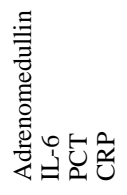 & 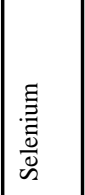 & E. & 离。 & 密它 & \\
\hline & $\begin{array}{l}\vec{E} \\
\vec{w}\end{array}$ & 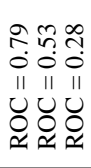 & $\begin{array}{l}0 \\
\infty \\
0 \\
11 \\
0 \\
0 \\
\approx\end{array}$ & 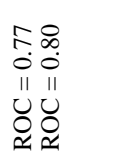 & 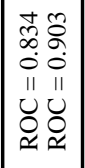 & $\begin{array}{l}n \\
\infty \\
0 \\
0 \\
11 \\
0 \\
\approx \\
\approx\end{array}$ & $\begin{array}{l}5 \\
\infty \\
0 \\
11 \\
0 \\
0 \\
\approx\end{array}$ & $\begin{array}{l}n \\
0 \\
11 \\
0 \\
0 \\
\simeq\end{array}$ & \\
\hline & 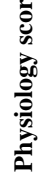 & 离 & 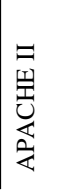 & 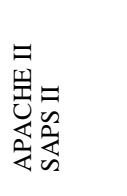 & 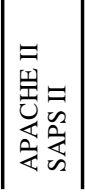 & $\begin{array}{l}\mathbb{x} \\
0 \\
0 \\
\infty\end{array}$ & 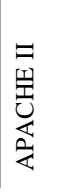 & 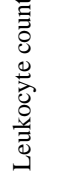 & \\
\hline
\end{tabular}


Table 4

Interventional studies registered with http://www.clinicaltrials.gov ${ }^{a}$

\begin{tabular}{|c|c|c|}
\hline Intervention & Trial number & Sponsor \\
\hline Activated protein $\mathrm{C}$ & NCT00604214 & Eli Lilly and Company \\
\hline Activated protein $\mathrm{C}$ with glucocorticoids & NCT00625209 & University of Versailles \\
\hline ART-123, recombinant soluble thrombomodulin & NCT00487656 & Artisan Pharma, Inc. \\
\hline Anti-tissue factor antibody & NCT00879606 & Altor Bioscience Corporation \\
\hline Microcirculation guided therapy & NCT00484133 & Onze Lieve Vrouwe Gasthuis \\
\hline Protocol-driven hemodynamic support & NCT00335907 & $\begin{array}{l}\text { National Institute of General Medical } \\
\text { Sciences }\end{array}$ \\
\hline Sodium selenite guided by procalcitonin & NCT00832039 & Biosyn Brahms AG \\
\hline Thymosin a 1 & NCT00711620 & Sun Yat-sen University \\
\hline Inhaled nitric oxide & NCT00608322 & National Institutes of Health \\
\hline Methylene blue, inhaled nitric oxide, combination of both & NCT00159510 & Northern State Medical University \\
\hline Eritoran, Toll-like receptor 4 antagonist & NCT00334828 & Eisai, Inc. \\
\hline Rapid administration of glucose, insulin, and potassium & NCT00823108 & Carolinas Healthcare System \\
\hline$n-3$ fatty acids for cognitive function & NCT00772096 & University Hospital, Basel, Switzerland \\
\hline Vasoactive intestinal peptide & NCT00004494 & $\begin{array}{l}\text { U.S. Food and Drug Administration Office } \\
\text { of Orphan Products }\end{array}$ \\
\hline Ready-to-use parenteral nutrition & NCT00798681 & Fernandes Tavora Hospital \\
\hline External cooling & NCT00527007 & Assistance Publique, Hopitaux de Paris \\
\hline Glutamine and antioxidants & NCT00133978 & Kingston General Hospital \\
\hline Levosimendan versus dobutamine & NCT00093301 & Wentworth Area Health Services \\
\hline Factor V1a agonist & NCT01000649 & Ferring Pharmaceuticals \\
\hline Resuscitation studies & \multicolumn{2}{|l|}{ Trial numbers } \\
\hline Hydroxy-ethyl starch & \multicolumn{2}{|c|}{ NCT00962156, NCT00464204, NCT00273728 } \\
\hline Colloid (typically albumin) versus crystalloid & \multicolumn{2}{|c|}{ NCT00707122, NCT00318942, NCT00327704 } \\
\hline Antibiotic studies & \multicolumn{2}{|l|}{ Trial number } \\
\hline Meropenem & \multicolumn{2}{|l|}{ NCT00534287 } \\
\hline Liposome encapsulated amphotericin B & \multicolumn{2}{|l|}{ NCT00697944 } \\
\hline Azithromycin (macrolide antibiotic) for early therapy & \multicolumn{2}{|l|}{ NCT00708799 } \\
\hline Cotrimoxazole versus vancomycin for MRSA & \multicolumn{2}{|l|}{ NCT00427076 } \\
\hline Daptomycin versus vancomycin for MRSA & \multicolumn{2}{|l|}{ NCT00770341 } \\
\hline 30-min versus 3-h infusion of meropenem (antibiotic) & \multicolumn{2}{|l|}{ NCT00891423 } \\
\hline Renal dialysis and antibiotics & \multicolumn{2}{|l|}{ NCT00451373 } \\
\hline Duration of antibiotics for peritonitis & \multicolumn{2}{|l|}{ NCT00657566 } \\
\hline Adjusted antibiotic dosing in patients with renal failure & \multicolumn{2}{|l|}{ NCT00816790 } \\
\hline
\end{tabular}

${ }^{a}$ Current as of February 2010. Additional trials: Numbers NCT00975793 and NCT00510835 refer to early goal-directed therapy trials. Numbers NCT01025180*, NCT00987818*, and NCT00934011 refer to biomarker-guided antibiotic use trials (the asterisk indicates that procalcitonin is used as the biomarker). Numbers NCT00676897, NCT00452608, and NCT00450840 refer to statin studies. Numbers NCT00995839 and NCT00628160 refer to terlipressin (analog of vasopressin) studies. Numbers NCT00559130, NCT00490477, NCT00752245, NCT00241228, and 
NCT00332371 refer to hemofiltration or renal dialysis studies. Numbers NCT00670254, NCT01047670, and NCT00842933 refer to glucocorticoid studies. 
Table 5

Surviving Sepsis guidelines ${ }^{a}$

To be completed within $6 \mathrm{~h}$ of identification of severe sepsis

1. Measure serum lactate.

2. Obtain blood cultures prior to antibiotic administration.

3. Administer broad-spectrum antibiotic.

4. If patient is hypotensive and/or serum lactate is $>4 \mathrm{mmol} \mathrm{liter}^{-1}$ :

a. Deliver an initial minimum $20 \mathrm{ml} \mathrm{kg}^{-1}$ of crystalloid or an equivalent.

b. Administer vasopressors for hypotension not responding to initial fluid resuscitation to maintain mean arterial pressure $>65$ $\mathrm{mm} \mathrm{Hg}$.

5. In the event of persistent hypotension despite fluid resucitation (septic shock) and/or lactate $>4 \mathrm{mmol}^{\text {liter }}{ }^{-1}$ :

a. Achieve a central venous pressure of $>8 \mathrm{~mm} \mathrm{Hg}$.

b. Achieve a central venous oxygen saturation of $>70 \%$ or mixed venous oxygen saturation of $>65 \%$.

To be completed within $24 \mathrm{~h}$ of identification of severe sepsis

1. Administer low-dose steroids for septic shock.

2. Administer drotrecogin alfa (activated protein $\mathrm{C}$ ) in accordance with a standardized intensive care unit policy.

3. Maintain adequate glycemic control (usually between 70 and $150 \mathrm{mg} \mathrm{dl}^{-1}$ ).

4. Maintain a median inspiratory plateau pressure $<30 \mathrm{~cm} \mathrm{H}_{2} \mathrm{O}$ for mechanically ventilated patients.

${ }^{a}$ From Reference 133. 